Portland State University

PDXScholar

\title{
Chlorophyll Characterization of Three Mistletoes and the Chloroplast Ultrastructure within Aerial and Endophytic Tissues of Phoradendron Juniperinum
}

Wesley Emanuel Dubbs

Portland State University

Follow this and additional works at: https://pdxscholar.library.pdx.edu/open_access_etds

Part of the Biology Commons

Let us know how access to this document benefits you.

\section{Recommended Citation}

Dubbs, Wesley Emanuel, "Chlorophyll Characterization of Three Mistletoes and the Chloroplast Ultrastructure within Aerial and Endophytic Tissues of Phoradendron Juniperinum" (1994). Dissertations and Theses. Paper 4747.

https://doi.org/10.15760/etd.6631

This Thesis is brought to you for free and open access. It has been accepted for inclusion in Dissertations and Theses by an authorized administrator of PDXScholar. Please contact us if we can make this document more accessible: pdxscholar@pdx.edu. 


\section{THESIS APPROVAL}

The abstract and thesis of Wesley Emanuel Dubbs for the Master of Science in Biology were presented June 2, 1994 and accepted by the thesis committee and the department.

COMMITTEE APPROVALS:

Clyde IU. Calvin, Chair

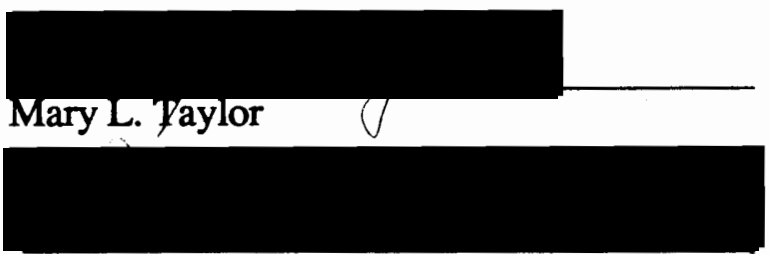

Richard D. Tocher

DEPARTMENT APPROVAL:

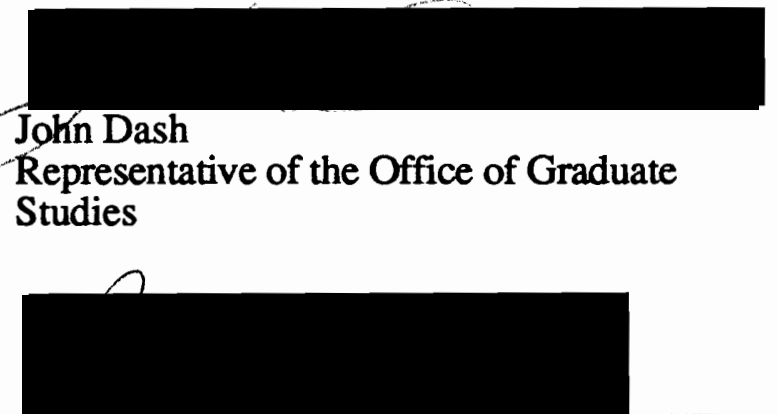

Robert O. Tinnin, Chair

Department of Biology

$* * * * * * * * * * * * * * * * * * * * * * * * * * * * * * * * * * * * * * * * * * * * * * * * * * * * * * * * * * *$

ACCEPTED FOR PORTLAND STATE UNIVERSITY BY THE LIBRARY

by

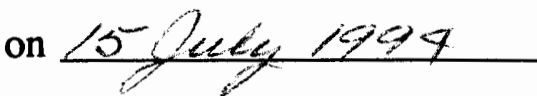




\begin{abstract}
An abstract of the dissertation of Wesley Emanuel Dubbs for the Master of Science in Biology: presented June 2, 1994
\end{abstract}

Title: Chlorophyll Characterization of Three Mistletoes and the Chloroplast Ultrastructure within Aerial and Endophytic Tissues of Phoradendron juniperinum

The aerial shoot pigments of three epiphytic mistletoes and their hosts were examined and the results were found to concur with earlier reports. Emphasis was placed on the mistletoe Phoradendron juniperinum. Absorbance spectroscopy indicated a very similar ratio of pigments in both the aerial tissue of the mistletoe and its juniper host. Spectroscopic examination found the presence of chlorophyll in the endophytic tissue of the genus Phoradendron for the first time. Total chlorophyll concentrations of the endophytic tissue of Phoradendron juniperinum were found to be approximately $10 \%$ that of aerial shoots. However, chlorophyll $a / b$ ratios of endophytic tissue were $40 \%$ of those in aerial tissue. The dwarf mistletoe Arceuthobium tsugense was found to have about $1 / 3$ the chl content of its host and of the two Phoradendron species examined. However, the endophytic concentrations of chlorophyll of $A$. tsugense were $250 \%$ higher than those found in compatible Phoradendron tissue.

Ultrastructural inspection of Phoradendron juniperinum revealed chloroplasts of the aerial shoots to be typical of $\mathrm{C} 3$ plants, yet they were small and contained little relative stroma lamella. This is characteristic of plants with unequal complement of the two photosystems. Examination of the endophytic system indicated that the most likely source of the chlorophyll to be plastids with enlarged thylakoid channels. These plastids were termed endophytic-chloroplasts

Experiments were performed to establish whether the synthesis of the chlorophyll within the endophytic system was via a light-independent pathway or by means of light penetration into mistletoe tissue and stimulation of the typical angiosperm light-dependent pathway. However, results as to the biosynthesis of chlorophyll were inconclusive. These experiments did indicate that chlorophyll was still present in 
endophytic tissue of Phoradendron juniperinum after 11 months without aerial shoots, whether enclosed in complete darkness or not. Microscopic examination of tissue did not revile the presence of any light conductive tissues in either the parasite or its host. 


\title{
CHLOROPHYLL CHARACTERIZATION OF THREE MISTLETOES AND THE CHLOROPLAST ULTRASTRUCTURE WITHIN AERIAL AND ENDOPHYTIC TISSUES OF PHORADENDRON JUNIPERINUM
}

\author{
by \\ WESLEY EMANUEL DUBBS
}

A thesis submitted in partial fulfillment of the

requirements for the degree of

\author{
MASTER OF SCIENCE \\ in \\ BIOLOGY
}

Portland State University

1994 


\section{ACKNOWLEDGMENTS}

In alphabetical order I would first like to thank those on my defense committee: my mentor, Dr. Clyde Calvin, for his support and encouragement, if it weren't for his initial interest in me as a graduate student I would not be where I am today; Dr. John Dash for his advice and for the hours of use of both the TEM and the dark room; Dr. Mary Taylor for her encouragement, supplies and comments regarding my thesis; and to Dr. Richard Tochur to whom I am grateful for his very pertinent criticisms of my thesis.

Other important people to thank include: Dr. Leonard Simpson for the use of his dark room, TEM advice and for the supplies necessary to complete many of my procedures; Judith for her advice and unending patience with all the problems associated with the fluorometer, Ken Tiekotter for his expertise in tissue processing for electron microscopy; Dr. Carl Wamser for the use of the absorbance spectrometer and the fluorometer; Dr. V. Franceschi, of WSU, for his help in interpreting my electron micrographs; and the people of the Biology and Chemistry stockrooms

Special appreciation is directed towards Jeanna Hammond, Mary Pfauth and Sherry Spencer for their constant support and encouragement.

And to Marcie Joy to whom I owe a great deal for her assistance in critiquing my thesis, which would otherwise be nothing but a jumble of words. 
TABLE OF CONTENTS

ACKNOWLEDGMENTS ....................................................... ii

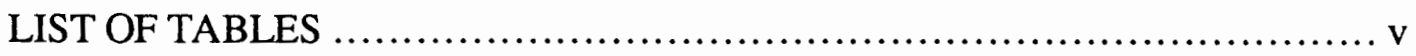

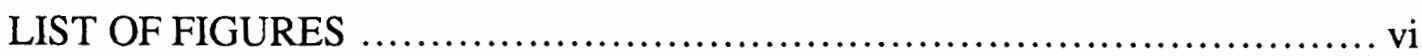

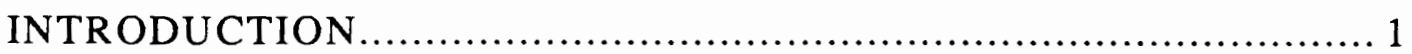

Material and methods......................................... 5

Plant Material

Dark Experiments

Pigment Extraction

Absorbance Spectroscopy

Fluorescence Spectroscopy

Thin Layer Chromatography

Light Microscopy

Transmission Electron Microscopy

Results 10

Absorbance Spectroscopy

Dark Experiments

Fluorescence Spectroscopy

Thin Layer Chromatography

Light Microscopy

Transmission Electron Microscopy 


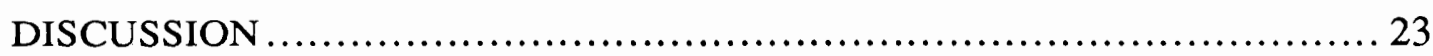

Shoot System Chlorophyll

Endophytic System Chlorophyll

Chloroplast Ultrastructure

Dark Experiments

Role of Chlorophyll

Conclusions

REFERENCES

\section{APPENDICES}

A Chlorophyll Biosynthesis Pathway ........................ 35

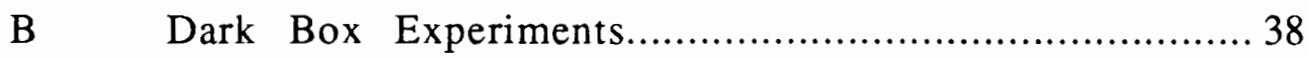




\section{LIST OF TABLES}

TABLE

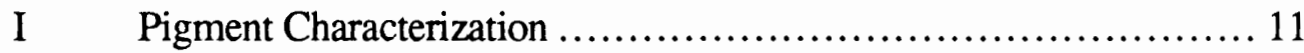




\section{LIST OF FIGURES}

\section{FIGURE}

1. Diagram of Endophytic System of Phoradendron juniperinum (gray area) on Host Stem

2. Absorbance Spectra of extracts from aerial Shoots of Phoradendron juniperinum and Juniper .............................. 10

3. Absorbance Spectra of Phoradendron juniperinum. Endophytic Tissue and Aerial Shoots $/ 10 \ldots \ldots \ldots \ldots \ldots \ldots \ldots \ldots \ldots \ldots \ldots \ldots$

4. Fluorescence of Protochlorophyllide and Chlorophyll............. 16

5. Chloroplasts in the Aerial Section of Phoradendron juniperinum..... 18

6. Endophytic-Chloroplasts in Control Longitudinal Strand 19

7. Endophytic-Chloroplast from Controls with Their Aerial Shoot Removed for 11 Months ....................................... 20

9. Endophytic-Chloroplast from Dark Box with Their Aerial Shoot Removed for 11 Months................................ 21

10. Endophytic-Chloroplast from Dark Box with Their Aerial Shoot Removed for 11 Months

11. Chlorophyll Biosynthesis.................................... 37

12. Dark Box Construction 40 


\section{INTRODUCTION}

Among the members of the Kingdom Plantae, parasitic angiosperms are unique in being dependent on other plants for water, minerals and often organic materials. These parasitic plants are separated into two groups based on their chlorophyll content (Marshall and Ehleringer 1990). Holoparasites are those that lack chlorophyll and are, therefore, dependent on their host for all carbohydrates and nutrients. Hemiparasites contain chlorophyll but they are often partially heterotrophic on host carbohydrates. Phoradendron juniperinum (Viscaceae) is an epiphytic, squamous (scale-leaf) mistletoe that is found as an obligate parasite on the branches of juniper, including the Westem Juniper, Juniperus occidentalis. P. juniperinum is considered a hemiparasite, since it contains chlorophyll and is able to produce energy through photosynthesis. It is a xylem-tapping mistletoe but is, to an extent, heterotrophic, obtaining $61-62 \%$ of its fixed carbon via uptake of dissolved organic compounds from the host's xylem stream (Marshall and Ehleringer 1990).

Angiosperms have two types of pigments in their chloroplasts: chlorophylls and carotenoids. There are two main kinds of chlorophyll in angiosperms, chlorophyll a and chlorophyll $b$. Both act as accessory pigments, absorbing different wavelengths of light and transferring that energy to special chlorophyll a photoreaction centers located in the thylakoid membrane of chloroplasts. This captured energy is used to drive the light reaction of photosynthesis. Carotenoids also act as accessory pigments in photosynthesis and, by acting as a preferred compound for photoxidation (oxygendependent bleaching of chlorophyll), they protect chlorophyll from potentially harmful short-wavelength light. This protective role explains why carotenoids concentrations are often seen to increase with increased light intensity (Kirk and Tilney-Bassett 1978).

In angiosperms, chlorophyll synthesis is closely related to the plastid structure and development (Virgin et al. 1963). All of the chlorophyll molecules and most carotenoids are contained in plastids. Plastids destined to become chloroplasts typically differentiate in the dark to form etioplasts with abundant prolamellar bodies which lack chlorophyll (Kirk and Tilney-Bassett 1978). When exposed to light, the lattice arrangement of the prolamellar bodies breaks down as the precursor molecule, 
protochlorophyllide, is esterified into chlorophyll, and the formation of the thylakoid membrane begins.

The endophytic system (longitudinal strands and sinkers) of mistletoe is considered to be a modified root system (Dawson and Ehleringer 1991). From the point of infection longitudinal strands grow acropetally, basipetally and laterally in the bark of the host branch. Sinkers arise from the longitudinal strands, and, upon reaching the host's vascular cambium, form their own cambial zone and establish a coordinated, centrifugal, growth with the host vascular cambium (Salle 1979) (figure 1). Subsequently the oldest part of a sinker is found deep within host tissue (as deep as $1 \mathrm{~cm}$ for those plants examined). When thick cross sections are made in fresh host tissue encompassing endophytic tissue, a green pigmentation is seen predominantly in the longitudinal strand (not including vascular tissue) and in the oldest, deepest part of the living sinker (Thoday 1956; Brian Fineran and Brian Malloy personal communications). The presence of chlorophyll and its photosynthetic activity has been documented within the endophytic system of Arceuthobium oxycedri (Viscaceae) (Rey et al. 1992). However, the presence of chlorophyll within the endophytic tissue of the genus Phoradendron has not been documented.

Chlorophyll production in angiosperms is believed to require light for activation of the chlorophyll biosynthesis (Castelfranco and Beale 1983) (Appendix A). Thus, if chlorophyll is found within the endophytic system of Phoradendron juniperinum it must be the result either of light penetration of host tissue and stimulation of the chlorophyll biosynthesis pathway or the result of a light-independent pathway for chlorophyll synthesis.

The penetration of light into plant tissue via fiber optics (Vogelmann 1989) or epidermal focusing (Martin et al. 1989; Bone et al. 1985) has been studied previously in plants. Because of light scattering, light entering a plant by fiber optics attenuates rapidly, becoming very diffuse at $0.1-0.2 \mathrm{~mm}$ depths in irradiated lettuce seeds (Vogelmann 1989). Of the incident 450 and $680 \mathrm{~nm}$ light striking the leaf surfaces, $90 \%$ was removed by the first $50 \mu \mathrm{m}$ of tissue and explains why many leaves are so thin, 80-250 $\mu \mathrm{m}$ (Vogelmann 1989). Epidermal focusing by specialized cells can concentrate light up to 20 times (Bone et al. 1985) and, in combination with fiber optics, may allow light to penetrate deeply enough into host tissue to stimulate the biosynthesis of chlorophyll. 


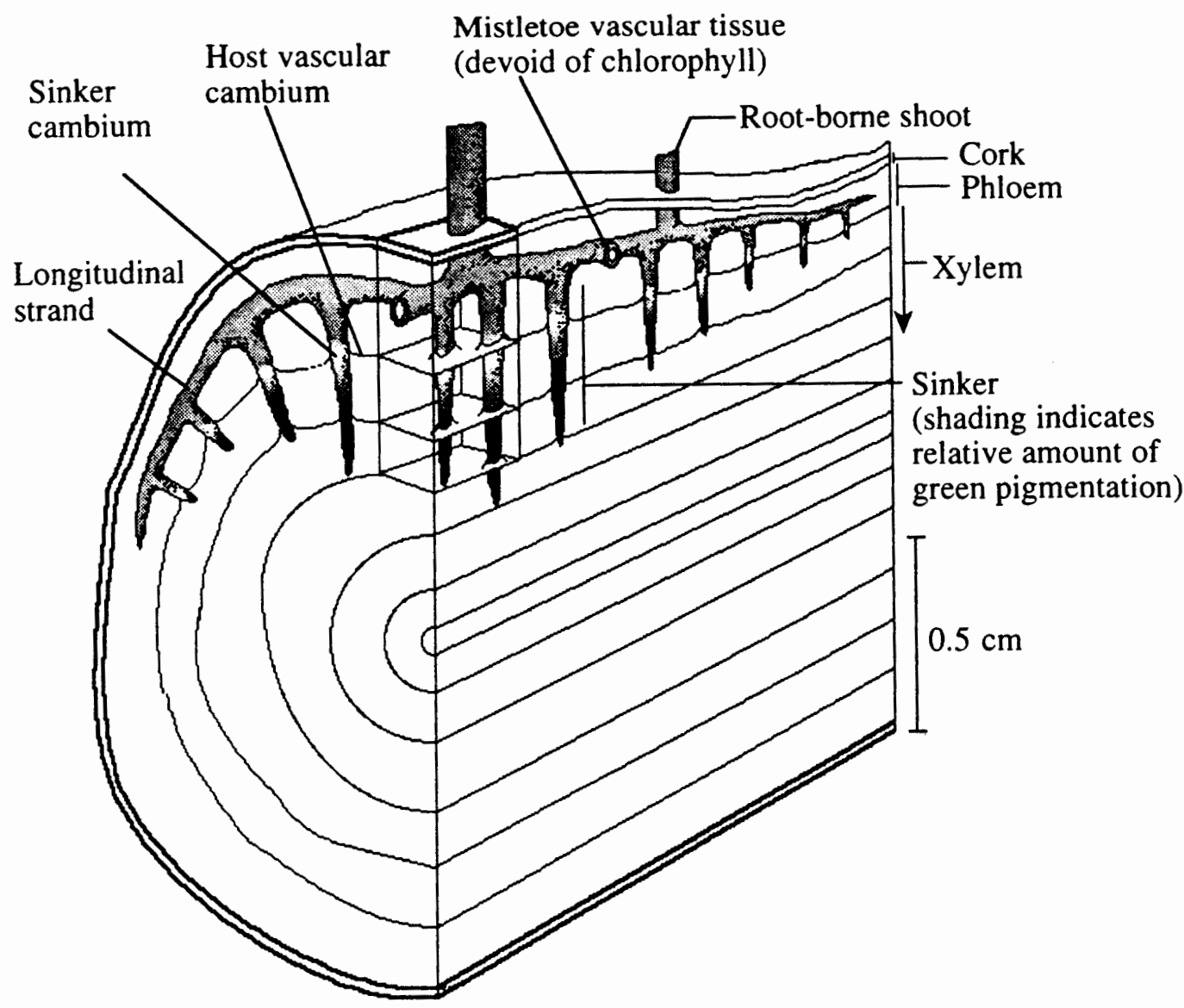

Figure 1. Diagram of endophytic system of Phoradendron juniperinum (gray area) on host stem.

To a varying extent, gymnosperms and other non-flowering plants are able to form chlorophyll in the dark without a prior light exposure (Castelfranco and Beale 1983) and form normal chloroplasts (Michel-Wolwertz and Bronchart 1974) through a light-independent pathway. However, in gymnosperms light-independent chlorophyll biosynthesis is believed to occur predominantly within cotyledons of young seedlings, when associated with the megagametophyte (Virgin and Egneus 1983) or, artificially, with the addition of cytokinins to cotyledons (Jansson et al. 1992). Adult plants as well have been shown to synthesize chlorophyll in the dark, however the amount formed in light is always substantially higher (Kasemir and Mohr 1981). 
The chlorophyll content of mistletoe has been examined previously (Hull and Leonard 1964; Eliás 1987; Shah et al. 1987; Rey et al. 1992). Chloroplast ultrastructure has been examined in Viscum album (Hudák and Lux 1986; Dodge and Lawes 1974), Striga hermonthica and Tapinanthus dodoneifolius (Tuquet and Salle 1991). None of these studies however have addressed the plastid ultrastructure within the endophytic system and, except for Arceuthobium oxycedri (Rey et al. 1992), chlorophyll characterization has been limited to examination within aerial shoots.

The purpose of this thesis is to characterize and document the pigments found in aerial and endophytic tissues of Phoradendron juniperinum, $P$. villosum and Arceuthobium tsugense and their hosts. The ultrastructure of plastids of $P$. juniperinum in both aerial shoots and the endophytic system were examined, and these tissues and those of its host were examined for the presence of light conductive cells. Experiments were conducted to determine whether chlorophyll was being synthesized in the endophytic system via light stimulation or by a light-independent pathway. 


\section{MATERIALS AND METHODS}

\section{Plant Material}

In addition to Phoradendron juniperinum (Englem.) ex A. Gray subsp. juniperinum, two other species of mistletoes were examined: Phoradendron villosum (Nutt.) Nutt. subsp. villosum, and Arceuthobium tsugense (Rosendahl) G. N. Jones. Pigment concentrations of all three mistletoes were examined spectroscopically. Emphasis was placed on $P$. juniperinum and, experiments and electron microscopy were performed.

Arceuthobium tsugense infected Tsuga heterophylla (Rafinesque) were collected on January 15, 1994, southwest of Estacada, Oregon. Phoradendron villosum epiphytic infections on Quercus garryana (Dougl.) were collected in early April, before bud brake on host, along Interstate Five south of Salem, Oregon. The location of the $P$. juniperinum infected Juniperus occidentalis (Hook) study site was about one $\mathrm{km}$ west of Tumalo, Oregon off Highway 20, in a juniper forest about 100 meters south of the intersection of Market Road and Highway 20. All experiments and collections were done on material taken between 1.5 to 3 meters from the ground on trees. Only those mistletoes growing on host branches with diameters of approximately $1.5 \mathrm{~cm}$ were used. Older, healthy mistletoe infections were chosen, as they are more likely to have a well-developed endophytic system. Plant tissue was stored in plastic bags, on ice, until return to Portland, Oregon. Voucher specimens of parasites and their hosts are deposited at Portland State University herbarium (HPSU).

\section{Dark Experiments}

Controls, aluminum wrappings and dark boxes experiments (Appendix B) were initiated on Phoradendron juniperinum infected juniper on April 20, 1993 and collected at intervals until March of 1994.

\section{Pigment Extraction}

All extractions were done in physiological darkness, using a green safe-light to prevent the photobleaching of pigments and to prevent any possible activation of 
chlorophyll biosynthesis. The safe-light was constructed using a modification of that described by Schiff (1972). Each of two 16" fluorescent tubes was covered by four sheets of amber cellophane and three sheets of green cellophane. The ends of the tubes were wrapped with tape to prevent light leakage from around the cellophane. The physiological darkness of the safe light was determined by its inability to stimulate chlorophyll production in etiolated pea seedlings (Adamson 1985).

Fresh weights of plant tissue were determined, and extractions were performed. In a mortar and pestle, 0.5 grams of chopped plant tissue ${ }^{1}$ were ground using acid washed quartz sand in acetone. To neutralize any acidity, and thus prevent pheophytin (magnesium-free chlorophyll derivatives) formation, 0.15 grams of $\mathrm{Na}_{2} \mathrm{CO}_{3}$ was added at the time of grinding. Acetone (100\%) was used, as it does not extract water soluble tannins that might interfere with the determination of the peaks for the shorter wavelength absorbing carotenoids yet, $100 \%$ acetone does not extract protochlorophyllide readily. Therefore, for the identification of protochlorophyllide, $80 \%$ acetone was used on the same sample immediately following the $100 \%$ extraction.

Extractions were performed using $5 \mathrm{ml}$ aliquots of the solvent and decanting through a Whatman glass microfibre filter $(1.2 \mu \mathrm{m}$ pore size $)$ placed over a sintered glass filtered funnel, assisted by a vacuum created by a water aspirator. This procedure was repeated on the plant tissue at least seven times to insure complete removal of pigments. The filter was then rinsed with the solvent several times and the resultant solution brought up to $45 \mathrm{ml}$.

\section{Absorbance Spectroscopy}

The absorbance spectrum of chlorophyll is a distinct indicator for its presence and was used to determine chlorophyll concentrations above $1 \mu \mathrm{g} / \mathrm{ml}$. Below this level, relative fluorescence was used to determine chlorophyll concentration (Kamiya et al. 1981).

1Endophytic tissue was obtained by first removing the cork tissue of the host stem then, using a razor blade or a hand trimmer, infected tissue was removed for extraction (only tissue away from where an aerial shoot emerged was used). Because Arceuthobium tsugense and Phoradendron juniperinum are both squamous mistletoes, only their photosynthetic stems were used for determination of aerial chlorophyll content. For $P$. villosum, leaves were used for extractions. 
Within quartz cuvettes the absorbance spectrum of bulk pigment extract was determined using a Shimadzu UV-visible recording UV-260 spectrometer, scanning from $350-700 \mathrm{~nm}$. Raw data was transferred digitally to a computer for accurate determination of absorbance readings. Total carotenoids, total chlorophyll, chlorophyll a, and chlorophyll b concentrations were calculated using the equations of Lichtenthaler (1987).

For acetone $80 \%(\mathrm{v} / \mathrm{v})$ extractions the following formula was used.

Results in micrograms per gram fresh weight of plant tissue:

$$
\begin{gathered}
\text { Chlorophyll } \mathrm{a}=\left(12.25 \mathrm{~A}_{663.2}-2.79 \mathrm{~A}_{646.8}\right) / \mathrm{Dilution} \text { factor } \\
\text { Chlorophyll } \mathrm{b}=(21.50 \mathrm{~A} 646.8-5.10 \mathrm{~A} 663.2) / \mathrm{Dilution} \text { factor } \\
\text { Total Chlorophyll }=(7.15 \mathrm{~A} 663.2+18.71 \mathrm{~A} 646.8) / \mathrm{Dilution} \text { factor } \\
\text { Total Carotinoids }=\left(\frac{1000 \mathrm{~A}_{470}-1.82 \mathrm{Chl}_{\mathrm{a}}-85.02 \mathrm{Chl}_{\mathrm{b}}}{198}\right) / \text { Dilution factor }
\end{gathered}
$$

For acetone $100 \%(\mathrm{v} / \mathrm{v})$ extractions the following formula was used. Results in micrograms per gram fresh weight of plant tissue:

$$
\begin{gathered}
\text { Chlorophyll } \mathrm{a}=(11.24 \mathrm{~A} 661.6-2.04 \mathrm{~A} 644.8) / \mathrm{Dilution} \text { factor } \\
\text { Chlorophyll } \mathrm{b}=(20.13 \mathrm{~A} 644.8-4.19 \mathrm{~A} 661.6) / \mathrm{Dilution} \text { factor } \\
\text { Total Chlorophyll }=(7.05 \mathrm{~A} 661.6+18.09 \mathrm{~A} 644.8) / \mathrm{Dilution} \text { factor } \\
\text { Total Carotinoids }=\left(\frac{1000 \mathrm{~A}_{470}-1.90 \mathrm{Chl}_{\mathrm{a}}-63.14 \mathrm{Chl}_{\mathrm{b}}}{214}\right) / \text { Dilution factor }
\end{gathered}
$$

The blanks used for the plant tissue was acetone, of the appropriate concentration.

\section{Fluorescence Spectroscopy}

Using the same bulk pigment extracts as those obtained for absorbance spectroscopy, fluorescence spectra were made using a SPEX Fluorolog 2, single beam spectrophotometer. Data acquisition and processing were done with a SPEX DM1B Spectroscopy Laboratory Coordinator. Specimens were excited using $432 \mathrm{~nm}$ light, and the right angle emittance was recorded from $600-750 \mathrm{~nm}$ with a Hamanatsu photomultiplier tube, R938 (Kamiya et al. 1981). Fluorescence spectra were corrected for the spectral intensity variation of the 1908 Standard Lamp with $0.3 \%$ rhodamine B, 
as the quantum counter. When bulk pigments are extracted with acetone and excited with $432 \mathrm{~nm}$ light chlorophyll a fluoresces at about $670 \mathrm{~nm}$ (Ikegami 1984). Using the $670 \mathrm{~nm}$ peak as an indication for the relative concentration of total chlorophyll, low concentrations of chlorophyll were determined and corroborated absorbance results.

The presence of protochlorophyllide can also be determined using fluorescence. By excitation of $80 \%$ acetone bulk pigment extract with $432 \mathrm{~nm}$ light, protochlorophyllide fluoresces at approximately $632 \mathrm{~nm}$ (Kamiya et al. 1981).

\section{Thin Layer Chromatography}

Thin layer chromatography (TLC) was done using a variation of that by Zweig and Sherma (1972). Pigments were extracted from plant tissues using the same procedure as with bulk pigment extraction for absorbance spectroscopy but using only $100 \%$ acetone. The resultant pigment extract was then placed in a separatory funnel, and a small amount of petroleum ether (b.p. $40-60^{\circ} \mathrm{C}$ ) was added. This solution was swirled gently to insure pigment migration into the petroleum either. An excess of $10 \%$ $\mathrm{NaCl}$ solution was then added to cause a phase separation of the pet ether and acetone/10\% $\mathrm{NaCl}$ solution. The lower acetone solution was discarded. The upper pet ether phase, containing pigments, was removed to a small beaker.

A Whatman Linear-K Pre-absorbent $5 \times 20 \mathrm{~cm}$ silica gel plate was activated by drying at $60^{\circ} \mathrm{C}$ overnight. The bulk pigments, in petroleum ether, were applied to the bottom of the TLC plate with a capillary tube. In a darkened fume hood the TLC plate was placed into the TLC chamber and allowed to develop for 30-45 minutes (hexane: ethyl ether: acetone in the ratio 60:30:20 ( $\mathrm{v} / \mathrm{v})$ was used as the developing solvent). To help minimize the amount of light exposure during pigment separation the TLC chamber was placed into the small cardboard box it was originally packaged in. When finished, the plate was remove from the chamber, and under low ultraviolet light, the solvent front and individual pigment migrations were marked to obtain data for determination of $\mathrm{R}_{f}$ values.

Individual pigments were retrieved by scraping off the desired pigment band and extracted by gentle mixing in $80 \%$ acetone. The solution was centrifuged, poured directly into cuvettes and analyzed for absorbance and fluorescence emissions as described above. 


\section{Light microscopy}

Tissue was examined which had previously been prepared according to Calvin et al. (1991). Approximately $3 \mathrm{~mm}$ diameter infected host stems were selected and cut directly into the fixative formalin-propionic acid-alcohol (FPA), and to aid infiltration a vacuum was applied several times. Tissue was dehydrated in a series of tert-butyl alcohol baths and infiltrated with paraffin over two weeks. Sections, $10-12 \mu \mathrm{m}$ thick were made using a rotary microtome and stained using safranine-fast green (staining in safranine for 6 hours and counter staining for 2 minutes in fast green) (Jensen 1962). Observations of tissue were made at $400 \mathrm{x}$ using a Zeiss compound microscope with a calibrated ocular lens.

\section{Transmission Electron Microscopy}

In physiological darkness, collected plant tissues were processed according a modification of Roland and Vian (1991). Tissues were trimmed to approximately $2 \mathrm{~mm}^{2}$ section and transferred directly into glutaraldehyde fixative (1.5\% glutaraldehyde and $1.5 \%$ paraformaldehyde in $0.1 \mathrm{M}$ cacodylate). Glutaraldehyde buffer was used, because it penetrates well, preserves proteins, and retains cellular components. Infiltration of fixative into tissue samples was aided by several applications of a vacuum.

Samples, in fixative, were kept in darkness at $4^{\circ} \mathrm{C}$ until the time of post fixation, $1-4$ days. Tissue was secondarily fixed using $2 \% \mathrm{OsO}_{4}$ buffered in $0.1 \mathrm{M}$ cacodylate at $10^{\circ} \mathrm{C}$ for two hours. Osmium tetroxide was used for post fixation, because it stabilizes unsaturated lipids and phospholipids that would otherwise be dissolved during dehydration with ethanol. Dehydration of tissue was performed using an ethanol series. Samples were transferred into L.R. White embedding solution (a methyl methacrylate), and polymerized within jell capsules at $60^{\circ} \mathrm{C}$ overnight. The resulting blocks were removed from the capsules, trimmed, and sections were made using a Sorvall Porter-Blum MT-2 ultramicrotome with a diamond knife.

Sections, on copper grids, were stained for four minutes with uranyl acetate, which enhances contrast of DNA and RNA (Roland and Vian 1991) and for 15 minutes with lead citrate (Reynolds 1963), which enhances cell membranes. To improve sample stability, sections were carbon coated. Examination and micrographs were made using a Hitachi HS7S transmission electron microscope. 


\section{RESULTS}

\section{Absorbance Spectroscopy}

Phoradendron juniperinum infections are typically easily seen on infected host trees as olive-green to yellow-green clumps of growth against the gray-green foliage of the juniper. Absorbance spectra of the bulk pigment extractions of the aerial positions of both the $P$. juniperinum and its host (figure 2 ) shows them to qualitatively have the same pigment complex. Table I indicates the qualitative and quantitative similarities between pigment concentrations in $P$. juniperinum and its host as shown by the highly comparable chlorophyll $\mathrm{a} / \mathrm{b}$ and carotenoid/chlorophyll ratios. Uninfected foliage of juniper had a statistically similar pigment complement as that of infected juniper, data not shown.

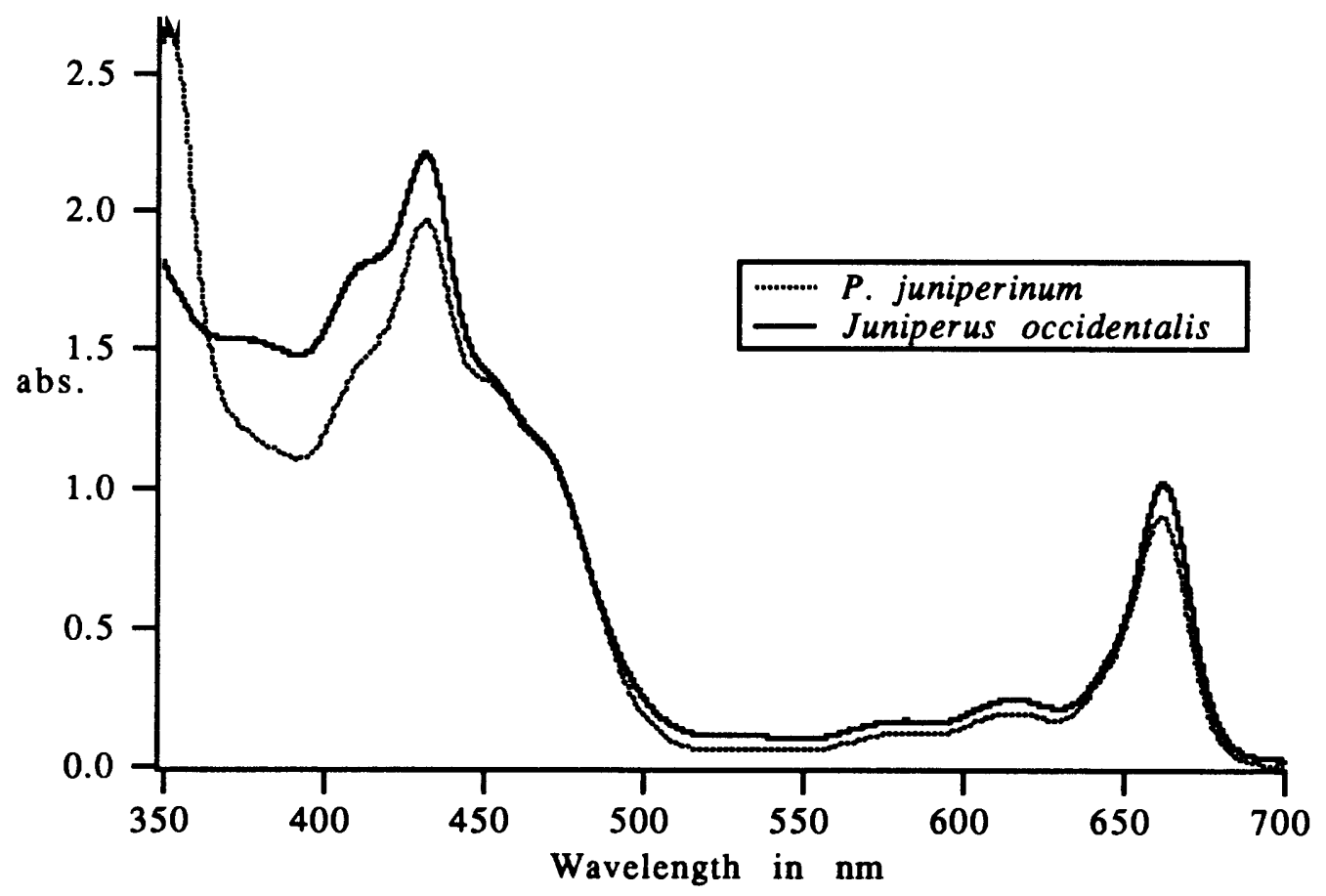

Figure 2. Absorbance spectra of extracts from aerial shoots of Phoradendron juniperinum and juniper. 
TABLE I

PIGMENT CHARACTERIZATION

\begin{tabular}{|c|c|c|c|c|c|c|}
\hline Sample & $\begin{array}{l}\text { Chl a } \mu \mathrm{g} / \mathrm{gr} \text {. } \\
\text { plant tissue }\end{array}$ & $\begin{array}{l}\text { ChI b } \mu g / g r . ~ \\
\text { plant tissue }\end{array}$ & $\begin{array}{r}\text { Total chl } \\
\mu \mathrm{g} / \mathrm{gr} \text {. plant } \\
\text { tissue }\end{array}$ & Chl ab & $\begin{array}{r}\text { Carotenoids } \\
\text { in } \mu \mathrm{g} / \mathrm{gr} . \\
\text { tissue }\end{array}$ & $\begin{array}{r}\text { Carotenoids } \\
/ \text { chl }\end{array}$ \\
\hline \multicolumn{7}{|l|}{ Phoradendron juniperinum } \\
\hline Aerial Shoot & $595 \pm 40$ & $232 \pm 30$ & $827 \pm 60$ & $2.56 \pm 0.32$ & $193 \pm 50$ & $0.23 \pm 0.04$ \\
\hline Lateral Endophytic & $52 \pm 22$ & $54 \pm 23$ & $106 \pm 36$ & $0.96 \pm 0.31$ & $18 \pm 4$ & $0.17 \pm 0.01$ \\
\hline Pseudoterminal Endophytic & $38 \pm 17$ & $34 \pm 18$ & $72 \pm 28$ & $1.12 \pm 0.43$ & $10 \pm 3$ & $0.14 \pm 0.03$ \\
\hline Seeds & 232 & 121 & 353 & 1.91 & 91 & 0.25 \\
\hline Al Wrapped Endophytic & $36 \pm 18$ & $22 \pm 17$ & $58 \pm 23$ & $1.64 \pm 0.33$ & $10 \pm 4$ & $0.17 \pm 0.03$ \\
\hline Dark Box Endophytic & na & na & $31 \pm 10$ & na & na & na \\
\hline $\begin{array}{l}\text { Endophytic with Aerial } \\
\text { shoots removed }\end{array}$ & na & na & $38 \pm 17$ & na & na & na \\
\hline \multicolumn{7}{|l|}{ Juniperus occidentalis } \\
\hline Aerial Shoot & $587 \pm 38$ & $227 \pm 27$ & $811 \pm 66$ & $2.62 \pm 0.39$ & $206 \pm 50$ & $0.26 \pm 0.06$ \\
\hline Dark Shoot & 296 & 203 & 499 & 1.45 & 80 & 0.16 \\
\hline \multicolumn{7}{|l|}{ Phoradendron villosum } \\
\hline Aerial & $521 \pm 58$ & $180 \pm 17$ & $701 \pm 59$ & $2.90 \pm 0.28$ & $322 \pm 33$ & $0.46 \pm 0.03$ \\
\hline Endophytic & na & na & $36 \pm 15$ & na & na & na \\
\hline \multicolumn{7}{|l|}{ Arceuthobium tsugense } \\
\hline Aerial & $144 \pm 28$ & $91 \pm 12$ & $236 \pm 35$ & $1.58 \pm 0.44$ & $82 \pm 30$ & $0.35 \pm 0.02$ \\
\hline Endophytic & $138 \pm 31$ & $145 \pm 26$ & $284 \pm 37$ & $0.95 \pm 0.34$ & $49 \pm 16$ & $0.17 \pm 0.04$ \\
\hline \multicolumn{7}{|l|}{ Tsuga heterophylla } \\
\hline Aerial & $506 \pm 80$ & $220 \pm 40$ & $726 \pm 109$ & $2.30 \pm 0.38$ & $183 \pm 29$ & $0.25 \pm 0.04$ \\
\hline Uninfected Host Bark & $88 \pm 4$ & $81 \pm 2$ & $169 \pm 4$ & $1.09 \pm 0.08$ & $31 \pm 10$ & $0.18 \pm 0.05$ \\
\hline
\end{tabular}


Absorbance spectroscopy of the pigment extract from the endophytic system of a lateral control infection yielded the spectrum seen in figure 3 . The spectrum is compared to that obtained from the aerial shoots which was divided by 10 to allow a more direct comparison to the endophytic system spectrum. The difference in the relative heights of the peaks (figure 3 ) indicate different concentrations of similar pigments as shown in table I. Both lateral and pseudoterminal infections were examined. Calvin et al. (1991) defines a lateral infection as one occurring along the sides of branches and a pseudoterminal as one where, as a result of cell death on the distal portion of a lateral infection, the infection becomes terminal on the branch. Table I shows the pigment concentrations of the endophytic tissue of lateral infections to be about a tenth that of the aerials. However, since removal of the endophytic system was done in physiological darkness, and that removal inevitably was accompanied by large amounts of host tissue, the actual concentrations of endophytic chlorophyll and carotenoids is larger than that indicated. This might explain some of the large range of error in the final values. Some error undoubtedly is due also to changes in chlorophyll concentration that occurred throughout the year in which tissue collections were made. However, results were not consistent enough to make any definite conclusions regarding seasonal variations in pigment content.

It was noted during removal of endophytic tissue for extraction that pseudoterminal infections showed a marked amount more necrotic tissue than did lateral infections. Table I shows that pseudoterminal infections have a lower chlorophyll concentration compared to lateral infections but had statistically similar chlorophyll $a / b$ and carotenoid/chlorophyll ratios. This could be due to increased amounts of necrotic tissue and a less elaborate endophytic system in pseudoterminal infections (Calvin et al. 1991) which might lower the percentage of living, chlorophyll containing, mistletoe cells removed for pigment extraction. The similar pigment ratios indicate that regardless of the presence of necrotic material, the endophytic system has a fundamentally similar pigment complement in both lateral and pseudoterminal infections. 


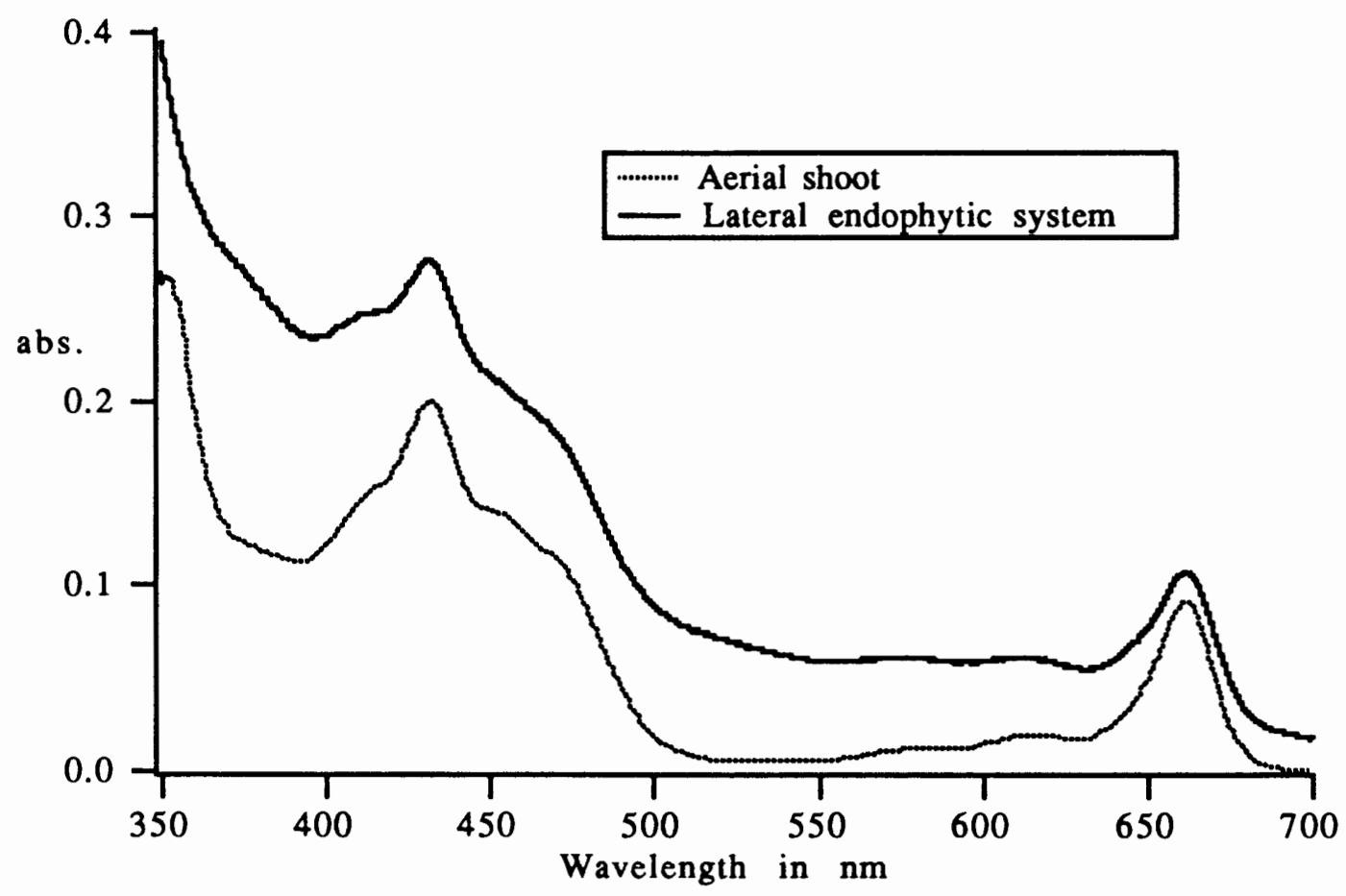

Figure 3. Absorbance spectra of Phoradendron juniperinum endophytic tissue and aerial shoots/10.

Dissected Phoradendron juniperinum seeds, collected in November, show green endosperm and embryos. Data from absorbance spectrum reveal approximately half the chlorophyll concentration, a lower chlorophyll $a / b$ ratio and a comparable ratio of carotenoid/chlorophyll to that of aerial shoots (table I). The viscin also contained a trace amount of chlorophyll (data not shown).

Chlorophyll was also found also in the endophytic systems of the oak mistletoe Phoradendron villosum and the hemlock dwarf mistletoe Arceuthobium tsugense ${ }^{2}$ (only lateral infections were examined) (table I).

Uninfected hemlock stems of a similar age as those collected with Arceuthobium infections also contained chlorophyll (table I). However, endophytic extracts contained about twice the concentration of pigments as the uninfected stems, resulting in similar

2 Arceuthobium tsugense's host, hemlock, was routinely found to contain chlorophyll within young cork or phloem cells, so as much of this material was removed as possible prior to pigment extraction. 
pigment ratios. These ratios were almost identical to those seen in the endophytic tissue of Phoradendron juniperinum. The endophytic system of $A$. tsugense had approximately the same total chlorophyll concentration as did aerial tissue with a higher average amount of chlorophyll $b$ but only about half the carotenoid concentration (figure 4).

The outer bark of Phoradendron villosum was covered with a prominent amount of lichen, so all bark was removed. Subsequently, chlorophyll concentrations recorded are only for sinker tissue. At the time of collection of $P$. villosum, its host (oak) had only recently begun bud break, so no data was obtained for the host aerial shoots. Chlorophyll content and pigment ratios were similar to that seen in $P$. juniperinum with ether notable exception of the carotenoid/chlorophyll ratio. This ratio may have been so high in $P$. villosum because its host had no shading foliage and thus carotenoid concentrations increased in aerial shoots, fulfilling their function in protecting chlorophyll from photoxidation. No pigment concentrations were determined for oak stems as the areas of the same age as infected branches were highly infested with lichen. Uninfected wood from similar locations as that removed for $P$. villosum sinker extractions lacked chlorophyll.

\section{Dark Experiments}

The photosensitive paper, which was kept within the dark boxes during the duration of the experiment, was processed. Only data from those four out of the five dark box set-ups in which the paper had not been exposed (showing darkness had been maintained) were used. Neither those control plants that had had their aerial portions removed nor those which were enclosed within dark boxes showed any regrowth of aerial shoots throughout the course of the experiment. Absorbance spectra of endophytic tissue extracts of these experiments did not indicate chlorophyll concentrations above $1 \mu \mathrm{g}$ per ml extract. Therefore, the extracts were examined with fluorescence spectroscopy. Consequently, no data was obtained conceming individual chlorophylls, chlorophyll ratios, or carotenoid concentrations.

Results of wrapping near-by infected juniper stems with aluminum foil show endophytic chlorophyll concentrations to be approximately half that of lateral control endophytic tissues. This discrepancy could be either the result of blocking light from reaching this tissue via light channeling or the result of where on the host branch this tissue was collected. Only tissue $1 \mathrm{~cm}$ in from both ends of the aluminum wrap was 
used for extraction. This limited the percentage of host tissue likely infected, as opposed to the control endophytic tissue that was collected in a closer proximity to the point of infections, and therefore was probably more concentrated with endophytic tissue. Chlorophyll $\mathrm{a} / \mathrm{b}$ ratios of aluminum wrapped stems were higher then that seen in controls. This higher chlorophyll $\mathrm{a} / \mathrm{b}$ ratio could be because of the reasons mentioned above, or because overall chlorophyll concentrations were low $1.3 \mu \mathrm{g} / \mathrm{ml}$ pigment extract and background absorbance by the spectrometer might have interfered with the chlorophyll $b$ peak. The value for chlorophyll $b$ has a higher probability for error, as it is calculated from absorption readings on a steep part of the combined chlorophyll a chlorophyll b curve (Lichtenthaler 1987).

Juniperus occidentalis, a gymnosperm, is presumably capable of biosynthesis of chlorophyll in dark. A small amount, $1.1 \mu \mathrm{g}$ chlorophyll/ml extract was noted just below the cork layer, in the phloem of young uninfected juniper tissue (data not shown). However, no chlorophyll pigments were noted in control bark of uninfected hosts of a similar diameter and age as those used for extraction. A shoot of juniper was found within one of the dark boxes that was in the dark for 11 months. Application of $2 \%$ tetrazolium gave a positive result (clear to red) that the shoot was respiring. Table I compares the pigment concentrations of this shoot with normal juniper shoots that had been growing under ordinary light. Nearly half the concentration of chlorophyll a was found in the dark grown juniper shoots as compared to light grown juniper shoots, while chlorophyll b concentrations were almost equal in both samples. This resulted in a low chlorophyll a/b ratio. These results differ from that typically obtained when young gymnosperm tissue is grown in darkness, which shows chlorophyll $\mathrm{a} / \mathrm{b}$ ratios to be higher in dark grown seedlings (Jansson et al. 1992) 


\section{Fluorescence Spectroscopy}

Absorbance spectra of the endophytic systems from the dark box experiments, the controls with their aerial-shoots-removed and Phoradendron villosum showed very low chlorophyll concentrations.. Accurate total chlorophyll concentrations were obtained from the $670 \mathrm{~nm}$ chlorophyll fluorescence peak (figure 4). Results showed endophytic tissues of both dark box and aerial-shoots-removed infections had only about $1 / 3$ the amount of chlorophyll as lateral controls. $P$. villosum sinker tissue had only $5 \%$ the chlorophyll concentration of its aerial shoots (table I).

No protochlorophyllide was found in the any of the Phoradendron juniperinum samples, so a test was done to check the accuracy of the fluorometer for determining protochlorophyllide. Peas were germinated in the dark, and the etiolated tissue was processed as outlined for pigment extraction, using $80 \%$ acetone as the solvent. This extract was examined using the fluorometer as described above. Figure 4 compares the fluorescence spectra of etiolated pea shoots and $P$. juniperinum endophytic tissue. The etiolated pea spectrum shows clearly the presence of a protochlorophyllide $632 \mathrm{~nm}$ peak, while none was seen in the $P$. juniperinum endophytic tissue.

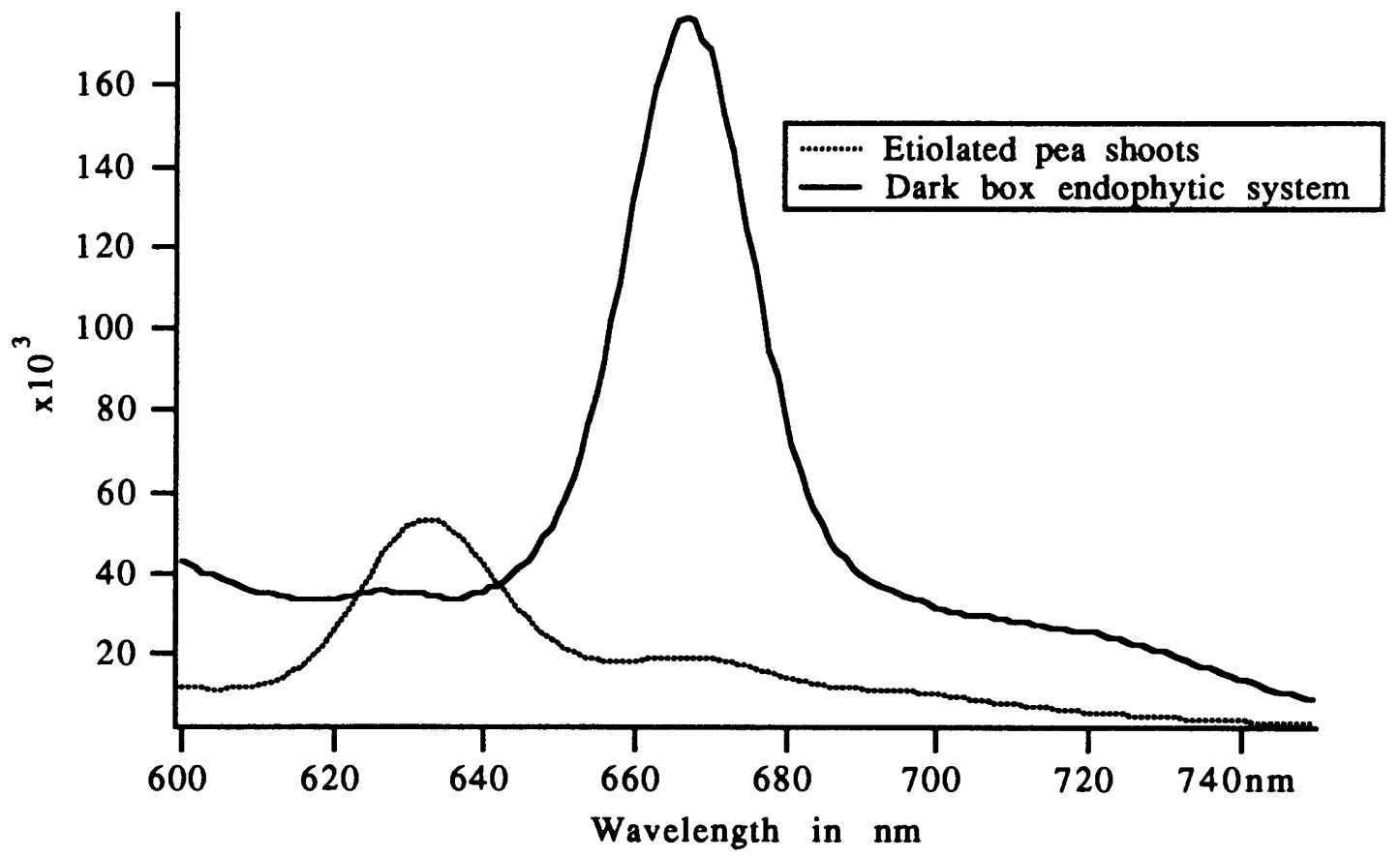

Figure 4. Fluorescence of protochlorophyllide and chlorophyll. 


\section{Thin Layer Chromatography}

Carotenoids have a strong absorbance between $400-500 \mathrm{~nm}$ but do not fluoresce. $R_{f}$ bands for Phoradendron juniperinum aerial shoots and endophytic tissue agree well with the expected migration of pigments, and the values indicate a typical angiosperm complement of pigments (Zweig and Sherma 1972). Table I shows the aerial carotenoid/chlorophyll ratios to be similar between the mistletoes and their prospective host. This concurs with the known role of carotenoids in protecting the photosynthetic apparatus.

\section{Light Microscopy}

Microscopically, distinguishing the cells of Phoradendron juniperinum from those of juniper was done by the noting the large nuclei and thick cell walls of mistletoe cells.

When thick cross sections of infected fresh juniper stems were made, a green pigmentation was observed within the longitudinal strands and in the deepest areas of sinkers. No pigmentation was seen near the cambial zone of the sinkers. Prepared slides of these tissues indicated that the oldest sinkers had been initiated in young host tissue (about one or two years old). The host cork layer covering longitudinal strands was approximately $0.1 \mathrm{~mm}$ thick. No light conductive cells, as described by Vogelmann (1989), were observed in either the parasite or its host.

\section{Transmission Electron Microscopy}

Chloroplasts found in the photosynthetic aerial stem of Phoradendron juniperinum are similar to those one would typically see in leaf tissue (figure 5). Yet were small ( $3 \mu \mathrm{m}$ long) and contained little relative stroma lamellae. These chloroplasts were lens shaped, with their longitudinal axes parallel to the cell wall and near the nucleus. They had a smooth plastid envelope with a moderate amount of grana and infrequently branching stroma lamellae (frets). Each granum consist of 3-12 stacks of thylakoids. Very few lipid bodies (plastoglobuli) were noted free within the stroma. 


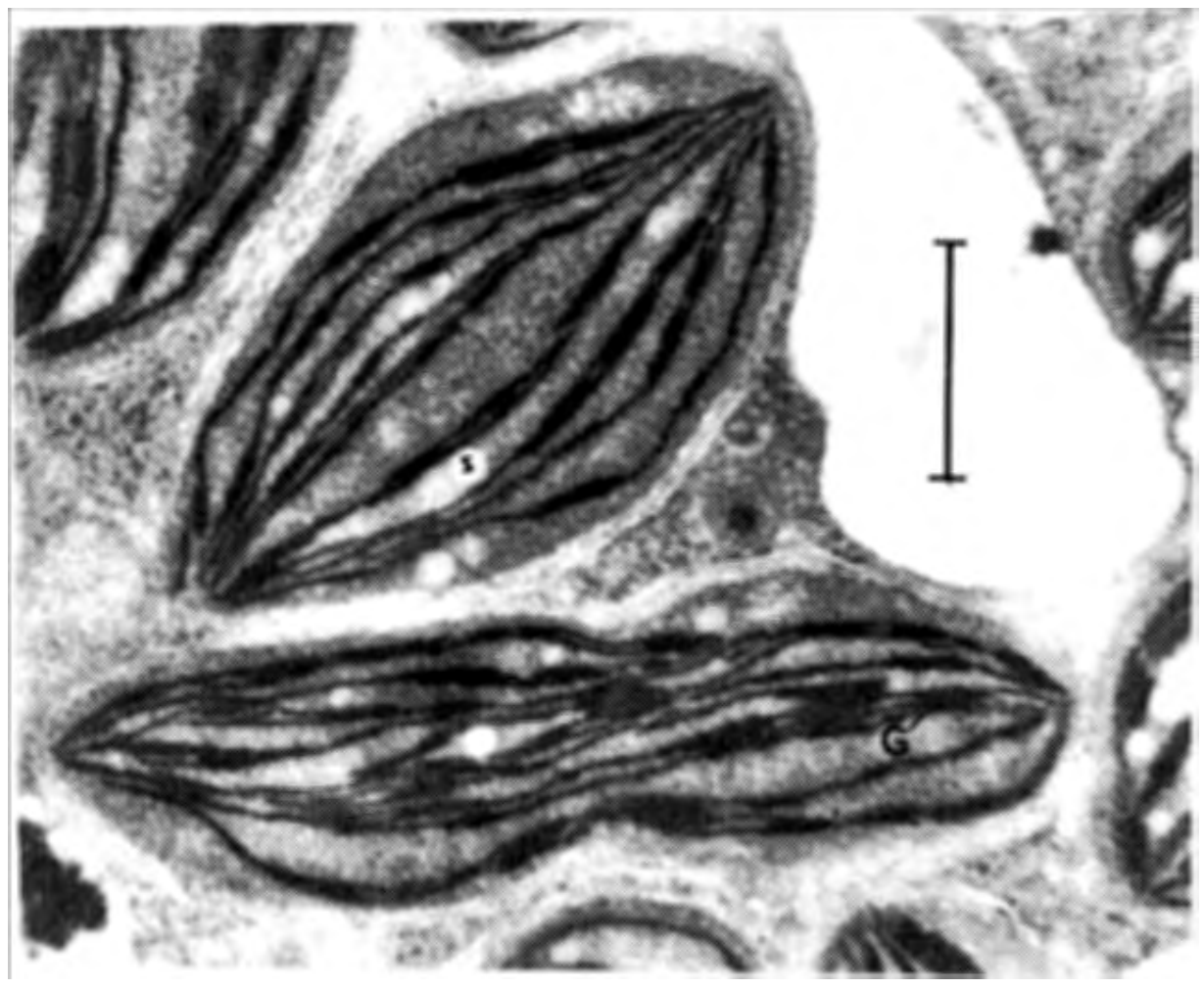

Figure 5. Chloroplasts in an aerial section of Phoradendron juniperimum. Note chloroplast at bottom of photo undergoing division $\mathrm{Bar}=1 \mu \mathrm{m}:$ S-starch, G-granum

A large number of plastids were found as amyloplasts in both longitudinal strands and sinkers (figures 6). The length of these amyloplasts varied from $2-3 \mu \mathrm{m}$ depending on the quantity of starch. Several of these amyloplasts showed areas of lightly staining thylakoid and are, therefore, a form of chloroplast. These plastids were termed endophytic chloroplasts. Endophytic-chloroplasts tended to have enlarged irregularly arranged thylakoid channels (the ruptured appearance of starch seen is a common artifact of amyloplasts processing). No endophytic-chloroplasts were identified within or near the sinker cambium. 


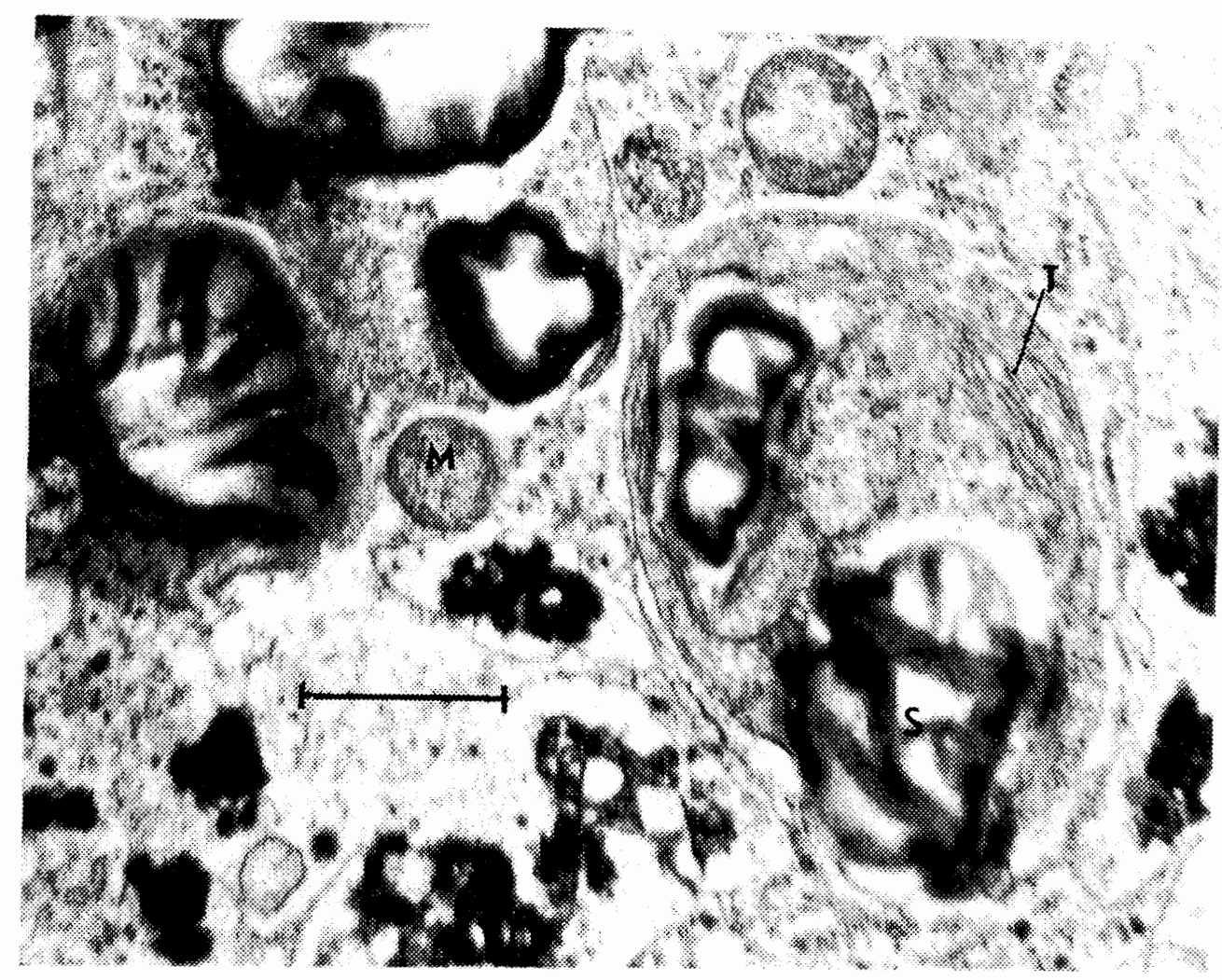

Figure 6. Endophytic-chloroplast in control longitudinal strand. Bar $=1 \mu \mathrm{m}: \mathrm{M}$-mitochondria, S-starch, T-thylakoid

Endophytic-chloroplasts were also found in the endophytic system of the controls that had their aerial shoot removed (figure 7). They were very similar to those seen in the dark box longitudinal strands and sinkers (figure 8). Compared to plastids in the control endophytic tissue, both longitudinal strands and sinkers in the experimental group tended to be smaller $(1-2.5 \mu \mathrm{m})$ have less starch and more prominent thylakoid with an enlarged thylakoid channel than in the control endophytic system (figure 9). Both groups had an approximately equal number of mitochondria with well developed cristae. Cytoplasmic content of cells of the experimental plants were much less dense than controls and contained no lipid bodies. 


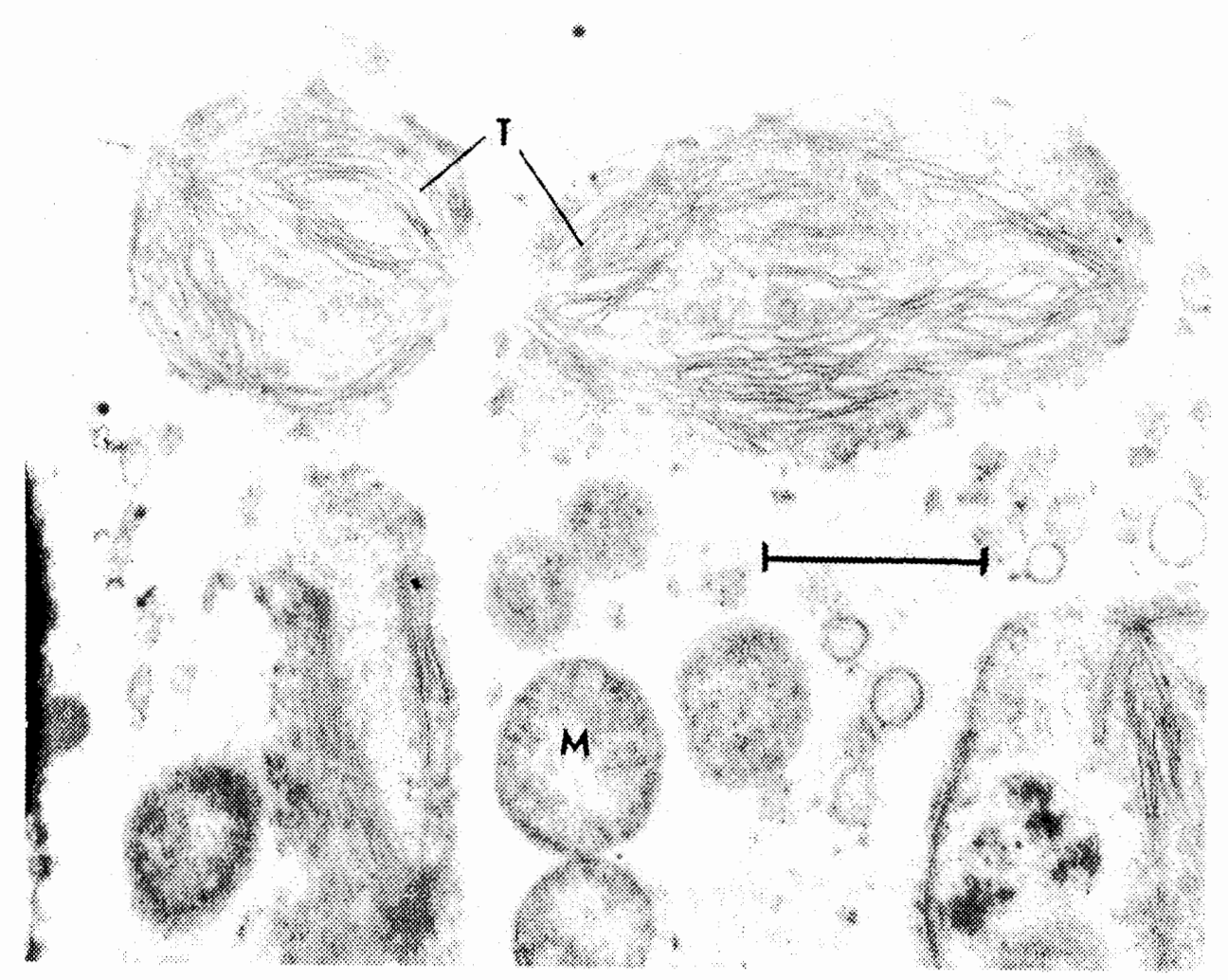

Eigure 2. Endophytic-chloroplasts from controls with their aerial shoots removed for 11 months. Bar = I $\mu \mathrm{m}$ : M-mitochondria, $T$-thylakoid 


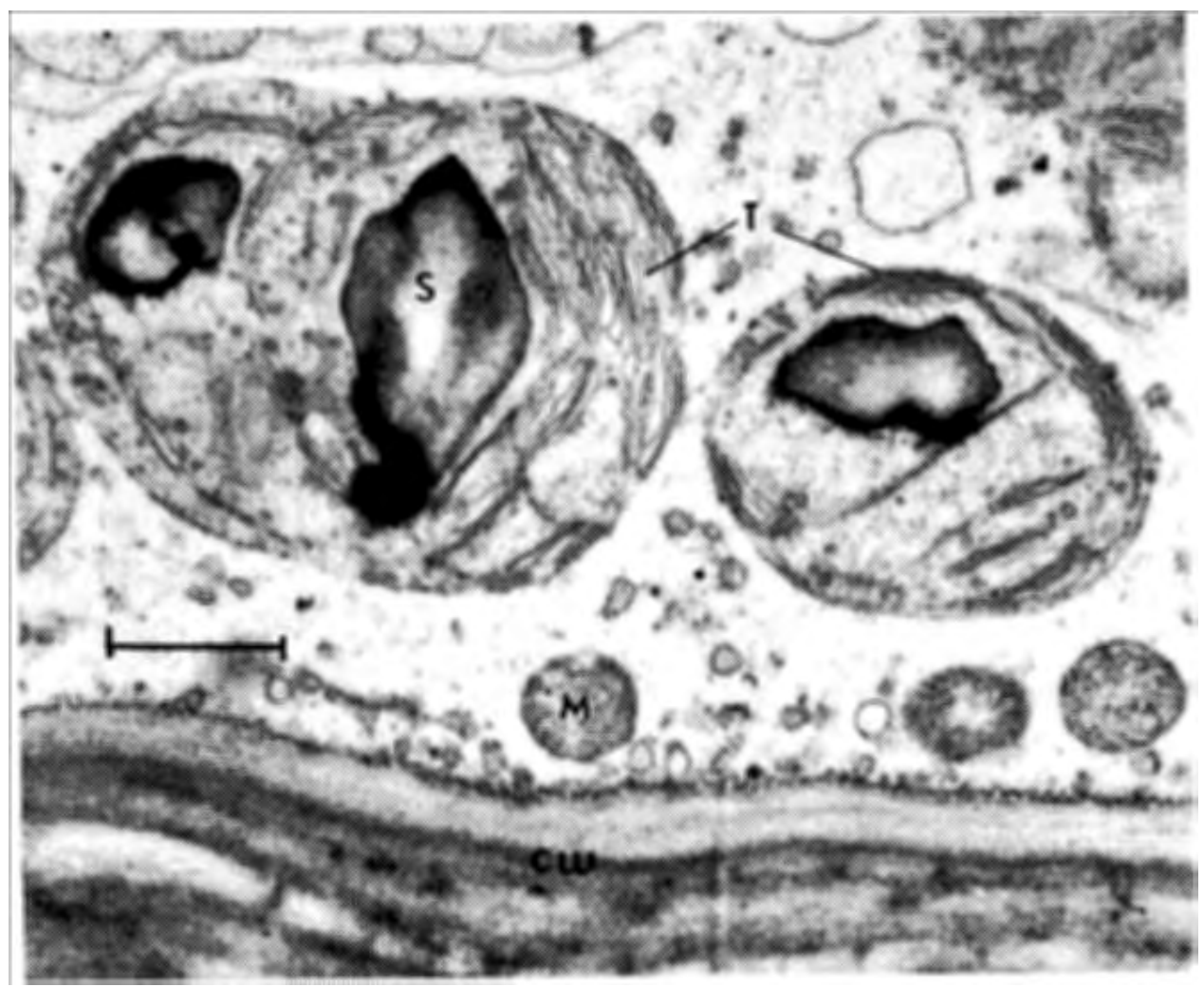

Gigure 8. Endophytic-chloroplasts from dark box with their aerial shoots removed for 11 months. Note the unusual amount of starch.

Bar $=1 \mu \mathrm{m}: \mathrm{M}$-mitochondria, S-starch, T-thylakoid, CW-cell wall 


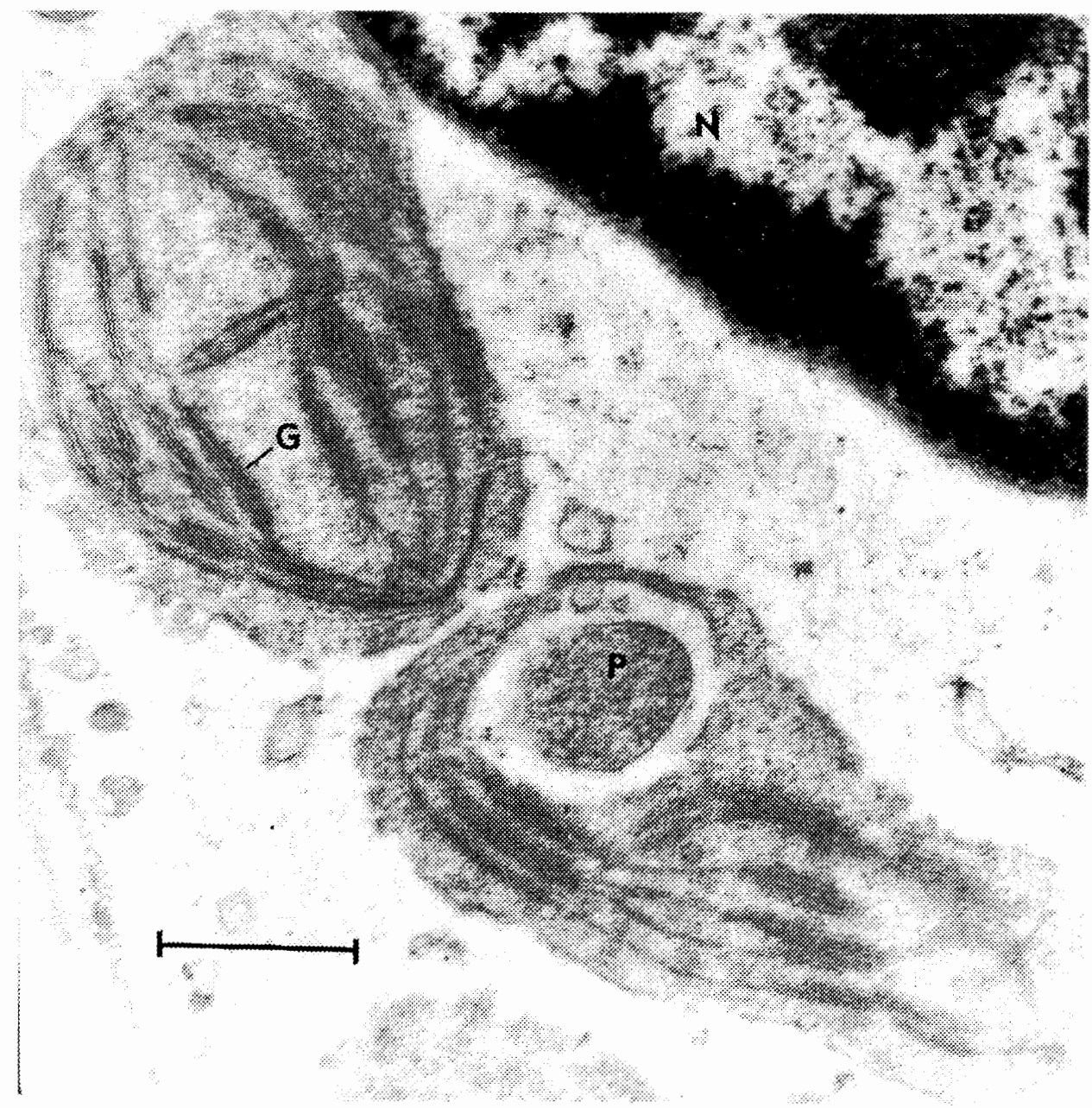

Figure 9. Endophytic chloroplasts from dark box with their aerial shoots removed for 11 months. Note the membrane bound proteinaceous body within the plastid and well developed thylakoids.

Bar $=1 \mu \mathrm{m}:$ P-proteinaceous body, Gingranum, N-nucleus 


\section{DISCUSSION}

\section{Shoot System Chlorophyll}

The degree of carbohydrate parasitism that xylem-tapping mistletoes exhibit is generally dependent on the quantity of chlorophyll they maintain (Marshall and Ehleringer 1990). Although total chlorophyll concentrations may vary, chlorophyll a/b ratios of mistletoes frequently parallel those of their hosts (Hull and Leonard 1964; Eliás 1987; Shah 1987; Tuquet and Salle 1991). This is the case for Phoradendron juniperinum, reported here, where not only was a similarity found between chlorophyll a/b ratios of host and parasite, but also they had similar chlorophyll and carotenoid content. These results concur closely with those reported by Hull and Leonard (1964) for $P$. juniperinum. The genus Arceuthobium has been reported to have only approximately $1 / 4$ the concentration of chlorophyll as compared to its host's tissue (Hull and Leonard 1964) and, thus, be more dependent on its host for carbohydrates (Arceuthobium's chlorophyll a/b ratios were not published). The species A. tsugense, reported here, had approximately $1 / 3$ the chlorophyll concentration, as well as a lower chlorophyll a/b ratio compared to its host, and of the two Phoradendron species studied. This low relative chlorophyll $\mathrm{a} / \mathrm{b}$ ratio resembles that found in angiosperm tissue grown in shaded conditions (Anderson 1986), though these samples were taken from the same areas as was the host tissue. The lower chlorophyll content of $A$. tsugense seems to indicate a greater parasitic affect on its host's carbohydrates than $P$. juniperinum has on its host. This has been confirmed by studies of photosynthetic rates and carbohydrate uptake on $P$. juniperinum (Marshall and Ehleringer 1990) and Arceuthobium (Stewart and Press 1990).

Chlorophyll found in the embryos and endosperm of $P$. juniperinum (an example of chloroembryos, embryos containing chlorophyll) (Palanisamy 1989) can be included with all four of the other mistletoes so far examined within the Loranthaceae and Viscaceae and found to have chlorophyllous embryos. This may not be an unusual occurrence, as one study indicates that a number of species show chlorophyllous embryos (Yakovlev and Zhukova 1980). 


\section{Endophytic System Chlorophyll}

Although some plants show chloroembryos, chlorophyll in roots is much less common. The genes controlling chlorophyll synthesis generally tend not to be expressed in the roots of species with well-developed photosynthetic aerial shoots (Mukai 1991). If chlorophyll is being synthesized in roots, the levels are typically low and require constant irradiation to stimulate its production (Oliveira 1981). All three of the mistletoes examined here have chlorophyll in their shoots and photosynthesize (Marshall and Ehleringer 1990; Rey et al. 1992), yet, they also contain chlorophyll within their modified root tissue, the endophytic system. Endophytic concentrations of chlorophyll and carotenoids in lateral infections of Phoradendron juniperinum were only approximately $10 \%$ of the value obtained for aerial shoots. This depressed pigment content could be due to the problems discussed, involving the separation of the endophytic tissue from the host tissue, however chlorophyll and carotenoid ratios were probably accurate. These difficulties in tissue removal also occurred in obtaining endophytic tissue for Arceuthobium tsugense, yet chlorophyll concentrations of the endophytic and aerial tissues were statistically equal (the carotenoid content was about $50 \%$ that of aerial shoots). This indicates either that $A$. tsugense's endophytic tissue has a significantly higher chlorophyll concentration than do the aerial shoots (to account for the lower proportion of parasitic tissue as the result of accompanying host tissue) or that the presence of the mistletoe increases the synthesis of chlorophyll within host bark tissue, which normally show only a moderate level of chlorophyll. The latter was not supported by spectroscopic examination of uninfected bark tissue that was near an infection nor by visual inspection of infected host tissue, which showed the greenest pigmentation within longitudinal strands and in the deepest, oldest tips of sinkers. These results differ from those for the juniper dwarf mistletoe, $A$. oxycedri (Rey et al. 1992), in which endophytic chlorophyll content was only $11 \%$ that of aerial tissue. Additionally chlorophyll $\mathrm{a} / \mathrm{b}$ ratios were similar in all $A$. oxycedri tissues. These differences could be due to species variation. The ratios of pigments within the endophytic systems of these mistletoes as well as in the bark tissue of Tsuga heterophylla were very much alike and may indicate the result of being in the same types of tissue and therefore a similar light regime. 


\section{Chloroplast Ultrastructure}

Ultrastructure of the chloroplasts from the mistletoes Striga hermonthica, Viscum album and Tapinanthus dodoneifolius, based on size, starch content and location in the plant body, show them to be of typical C3 flowering plants (Tuquet and Salle 1991) but to have a decreased relative amount and length of stroma lamellae compared with grana lamellae. The stroma lamellae is known to contain photosystem I (PSI). This low amount of relative stroma lamellae, coupled with having fewer chloroplasts per cell, (Tuquet and Salle 1991) lowers the overall efficiency of photosynthesis for these mistletces. I examined transmission electron micrographs of cited PSI deficient chloroplasts and determined a normal ratio of stroma lamellae to grana lamellae to be about 1:1 to 2:1 versus $2.5: 1$ for chloroplasts known to be deficient in PSI. Similar determinations of low relative stroma lamellae, 2.6:1, were made here for aerial chloroplasts of Phoradendron juniperinum and strengthens the point that it is partially heterotrophic (Marshall and Ehleringer 1990). Endophytic-chloroplasts were found deep within $P$. juniperinum's endophytic system, most prominently in longitudinal strands and the deeper, older ends of sinkers (as deep as $1 \mathrm{~cm}$ and up to 8 years old for those plants examined). The very enlarged thylakoid channel and the obstruction of thylakoid by starch grains made microscopic interpretation of the functionality of relative photosystems, based on proportional amounts of grana and stroma lamellae difficult. Examination of transmission electron micrographs of the endophytic systems of $\boldsymbol{P}$. macrophyllum (Calvin, personal communication) and Korthalsella lindsayi (Fineran 1987) showed plastids with thylakoid development. However, I am hesitant to make conclusions as to the nature and presence of these endophytic-chloroplasts, as no mention of chlorophyll was documented, and the proper dark processing of the tissue in darkness was unlikely.

\section{Dark Experiments}

Spectroscopy of the Phoradendron juniperinum infections that had their aerialshoots-removed for 11 months (whether within dark boxes or not) indicated a low amount of chlorophyll within their endophytic system. Starch was less abundant, and the observance of thylakoid more readily made than in control sections. After 11 months without aerial shoots only $80 \%$ of endophytic cells contained cytoplasmic contents. Though cytoplasmic content of the cells was less dense then controls, there were abundant mitochondria with well developed cristae. Tetrazolium application to this 
tissue indicated that the cells were still respiring. Carbohydrates, believed to delay the loss of chlorophyll (Mohanty 1991), taken up from the host xylem stream might have been responsible for maintaining chlorophyll within the endophytic system. It might also have made it possible for the mistletoe having retained living and metabolizing tissue during 11 months without aerial shoots. However, since the aerial portions of the plants were removed, no transpiration occurred, and so, any influx of host carbon is probably low (evaporation from the unsealed ends of cut shoots might have contributed to the uptake of xylem sap). The lower amount of starch seen in these cells implies that it was metabolized during the 11 months. If this was the sole source of carbohydrates (to survive for 11 months) metabolism must have been very low, and the tissue in a dormant, latent condition to minimize energy needs. This is likely the case, as no tissue growth was noted. $P$. juniperinum, restricted to sap wood, can become embedded within its host and remain living for 219 years (Meinecke 1912), the presence of chlorophyll was not documented.

The persistence of the chlorophyll found within the endophytic system from the dark boxes was surprising. Chlorophyll breakdown in the dark depends on the rate of chlorophyll turnover and is fast, beginning within 24 hours, in normally green tissues, such as leaves (Bennett 1981; Hendry and Stobart 1987). Virgin and Sundqvist (1992) found potato tubers accumulate a "stable" form of chlorophyll when continuously irradiated for one month then, after one month in darkness, little chlorophyll destruction had occurred. A large amount of protochlorophyllide always accompanied the chlorophyll found in the potato. Similarly, $P$. juniperinum's endophytic system acts as a storage organ, as noted by the large amount of starch found. However, unlike potato tubers, the endophytic system is, like leaves, persistently green except for the area near the cambium, and no protochlorophyllide was ever detected. If the chlorophyll found in sinkers is a form of light-stimulated "stable" chlorophyll, it was stable for 11 months without light. Chlorophyll degradation is rapid in darkness and increases with rising temperature (Okada et al. 1992). Yet, chlorophyll was maintained within endophytic tissue, in the dark, throughout the warm summer months.

There are two possible pathways of chlorophyll synthesis, light-dependent and light-independent. No recognizable light conductive cells were noted in the juniper cork or bark tissue nor in any mistletoe tissue that would have accounted for the transmittance of light into the endophytic tissue of Phoradendron juniperinum. The thin, loose arrangement of cork cells covering longitudinal strands may allow for light penetration, 
but the absorbance capacity of the chlorophyll within the longitudinal strands would preclude light from the deeper tissue of sinkers (Vogelmann 1989). Yet observations showed more green pigmentation at the deepest, oldest areas of sinker tips. This tissue would have been without light for several years, since the time of the sinker's inception, when it might have been close enough to the surface of the host stem to receive light. If the chlorophyll of $P$. juniperinum is formed in darkness, it is not necessarily "stable" for years but is constantly being resynthesized. Gymnosperms and other non-flowering plants are typically able to synthesize chlorophyll in the dark (Castelfranco and Beale 1983). However, normal angiosperm chlorophyll production via the $C 5$ chlorophyll biosynthesis pathway is dependent on two light reactions (appendix A).

There are studies where the "absolute" requirement of light absorption for the synthesis of chlorophyll in angiosperms is questioned (Boardman 1966; Kirk and Tilney-Bassett 1978). The most often cited found that when previously illuminated Tradescantia albiflora (Adamson 1980) and Zostera capricornii (Adamson 1985) were transferred into darkness, chlorophyll continued to accumulate for nine days in the same proportions as plants grown in light. It has been postulated that the photoreduction of protochlorophyllide to chlorophyllide can occur by means of a protochlorophyllide oxidoreductase that doesn't need light activation (Adamson and Packer 1984). These claims have been disputed as, in the dark, all ${ }^{14} \mathrm{C}$ labeled 5-aminolaevulinic acid in barley was found to be synthesized into protochlorophyllide not chlorophyll (Apel et al. 1984). However, Rudoi and Chkanikova (1989) found that ${ }^{14} \mathrm{C}$ labeled 5aminolaevulinic acid is synthesized into chlorophyll in Tradescantia. Noteworthy is that in these documented cases of "dark" chlorophyll biosynthesis involving angiosperms, plant tissue required an initial exposure to light; only then did plants put into darkness accumulate chlorophyll. This suggests that light must still be effecting the formation or activation of protochlorophyllide oxidoreductase and/or phytochrome $\mathrm{fr}_{\mathrm{fr}}$, and the accumulation of chlorophyll can only happen while these compounds are functioning. This could account for the time limit of nine days for chlorophyll accumulation as found by Adamson (1980 and 1985).

In these few studies of "dark" synthesis of chlorophyll in angiosperms, chlorophyll $\mathrm{a} / \mathrm{b}$ ratios were similar in both dark and light grown tissue (Adamson 1980 and 1985). Angiosperms that are grown at low illumination have lower chlorophyll $a / b$ ratio than those grown at high light intensity (Anderson 1986). The main factor controlling changes in chlorophyll $a b$ ratios is illumination. At decreased illumination 
chlorophyll $b$ increases because it more readily absorbs low energy light. On the other hand, when gymnosperm tissue is grown in darkness (Jansson et al. 1992), chlorophyll $\mathrm{a} / \mathrm{b}$ ratios tend to be higher. Comparison of these three scenarios would indicate that the lower chlorophyll $\mathrm{a} / \mathrm{b}$ ratio seen in the endophytic system, compared to aerial shoots of Phoradendron juniperinum, is the result of chlorophyll synthesis in low light. Yet this seems unlikely, since the chlorophyll found is deep within tissue and was stable in metabolizing tissue even after 11 months of darkness.

\section{Role of Chlorophyll}

Chlorophyll is not known to have a role other than that involved with photosynthesis. However, it was found in the endophytic system of Phoradendron juniperinum in tissue, which, at best, receives little light. Proposals for the presence of chlorophyll within stems (Bossard and Rejmanek 1992) suggest that chlorophyll: 1. extends the period of carbon gain during drought, heat, or shading when leaves are nonfunctional due to being drought deciduous stomatal closure or low light; 2 . increases inceptional growth rates of leaves and blossoms; 3 . allows for rapid recovery from leaf herbivory and; 4. offsets respiration in the stem. Any one or more of these could explain the presence of chlorophyll within longitudinal strands, if indeed, light is penetrating host cells, but can not explain its unexpected presence in sinkers, which appear to be too deep to receive light.

\section{Conclusions}

The results that seemed to indicate that the chlorophyll present within the endophytic system was produced via light stimulation were: the similarity of pigment ratios in similarly located tissue (endophytic and Tsuga heterophylla bark) and the resemblance of these ratios to the low chlorophyll ratios seen in plant tissues growing in shaded conditions; the relatively thin host cork layer observed over longitudinal strands may allow light penetration into subsequent endophytic tissue; and the fact that light, at least initially, is required for chlorophyll biosynthesis in angiosperms.

Results that indicated a light-independent pathway for chlorophyll synthesis were the observations that: chlorophyll was found far from the illuminated surface, deep within host tissue; chlorophyll was not broken down after 11 months of darkness; the similarity of the chlorophyll concentrations in the endophytic tissues of those plants 
which had had their aerial shoots removed, whether within dark boxes or left exposed to light; and no light conductive cells were noted in either the host or its parasite.

Although a definitive answer as to the pathway of chlorophyll biosynthesis in the three mistletoes was not resolved, much data was obtained for the presence of chlorophyll within the endophytic systems. The result obtained for aerial shoots confirm earlier reports on chlorophyll characterization of these mistletoes. However, comparisons between chlorophyll within aerial and endophytic tissues for Arceuthobium tsugense were dissimilar to A. oxycedri (Rey et al. 1992). This is the first time spectroscopy has confirms the green pigmentation seen in the endophytic system of Phoradendron to be chlorophyll. Plastid ultrastructural examination of the endophytic system of $P$. juniperinum showed the likeliest source for the chlorophyll to be chloroplasts with a loose enlargement of thylakoid channels. These plastids were termed endophytic-chloroplasts. More data must be collected to determine the mode of chlorophyll synthesis and what possible role it plays in the endophytic tissue.

Regrowth of aerial shoots within the dark box experiments could have resolved whether chlorophyll is being synthesized via a light-independent means. A modification of the dark box experiment to enclose just one mistletoe shoot and measurements of any new growth for pigment concentrations might help to clarify the synthesis of this unusual occurrence of chlorophyll. As would determination of the end product of dark administered ${ }^{14} \mathrm{C}$ labeled 5 -aminolaevulinic acid to be either protochlorophyllide or chlorophyll. The two photosystems in the endophytic system could be examined to determine their functionality. The observation that endophytic chlorophyll concentrations were higher than in aerial shoots of Arceuthobium tsugense are intriguing and would be worth pursuing as an option to Phoradendron juniperinum. 


\section{REFERENCES}

Adamson, H., Y., Hiller, Roger G., and Vesk, M. (1980). Chloroplast Development and the Synthesis of Chlorophyll $\mathrm{a}$ and $\mathrm{b}$ and Chlorophyll Complexes I and II in the Dark in Tradescantia albiflora (Kunth). Planta. 150: 269-274.

Adamson, H. and Packer, N. (1984). Dark Synthesis of Chlorophyll and Dark Reduction of Protochlorophyllide in Vitro by Pea Chloroplasts. In: Protochlorophyllide Reduction and Greening. Sironval, C. and Brouers, M. (Eds.). Marinus Nijhoff/Dr. W. Junk Publ. The Hague. pp 353-363.

Adamson, H., Packer, N. and Gregory, J. (1985). Chloroplast Development and the Synthesis of Chlorophyll and Protochlorophyllide in Zostera Transferred To Darkness. Planta. 165: 469-476.

Anderson, J. (1986). Photoregulation of the Composition Function and Structure of Thylakoid Membranes. Annual Revue of Plant Physiology. 37: 93-136.

Apel, K.; Motzkus, M.; and Dehesh, K. (1984). The Biosynthesis of Chlorophyll in Greening Barley (Hordeum vulgare). Is there a Light-Independent Protochlorophyllide Reductase? Planta. 161: 550-554.

Bennett, J. (1981. Biosynthesis of the Light-Harvesting Chlorophyll a/b Protein. Polypeptide Turnover in Darkness. European J Biochemistry. 118: 61-70.

Boardman, N. (1966). Protochlorophyll. In: The Chlorophylls. Academic Press. New York. pp 135-140.

Bone, R., Lee, D. and Norman, J. (1985). Epidermal Cells Functioning as Lenses in Leaves of Tropical Rainforest Shade Plants. Applied Optics. 24: 1408-1412.

Bossard, C. and Rejmanek, M. (1992). Why Have Green Stems? Functional Ecology. 6: 197-205.

Calvin, C., Wilson, C. and Varughese, G. (1991). Growth of Longitudinal Strands of Phoradendron juniperinum (Viscaceae) in Shoots of Juniperus Occidentalis. Annals of Botany. 67: 153-161.

Castelfranco, P. and Beale, S. (1983). Chlorophyll Biosynthesis: Recent Advances and Areas of Current Interest. Annual Review of Plant Physiology. 34: 241 278.

Dawson, T. and Ehleringer, J. (1991). Ecological Correlates of Seed Mass Variation in Phoradendron juniperinum, a Xylem-Tapping Mistletoe. Oecologia. 85: 332-342. 
Dodge, J. and Lawes, G. (1974). Plastid Ultrastructure in Some Parasitic and SemiParasitic Plants. Cytobiologie. 9: 1-9.

Eliás, P. (1987). Chlorophyll Contents in Leaves of a Mistletoe Loranthus europaeus Jazq. In: Parasitic Flowering Plants (Proceedings of the 4th International Symposium on Parasitic Weeds. Weber, H. and Forstreuter, W. (Eds.). Marburg. pp 171-173.

Fineran, B. (1987). Graniferous Treachery Elements in Haustoria of Parasitic Flowering Plants. In: Parasitic Flowering Plants (Proceedings of the 4th International Symposium on Parasitic Weeds, Marburg) Weber, $H$. and Forstreuter, W. (Eds.). Marburg. pp 197-200.

Hendry, G. and Stobart, A. (1986). Chlorophyll Turnover in Greening Barley. Phytochemistry. 25: 2735-2738.

Hudák, J. and Lux, A. (1986). Chloroplast Ultrastructure of Semiparasitic Viscum album L. Photosynthetica. 20: 223-224.

Hull, R. and Leonard, O. (1964). Physiological Aspects of Parasitism in Mistletoe (Arceuthobium and Phoradendron). II the Photosynthetic Capacity of Mistletoe. Plant Physiology. 39: 1008-1017.

Ikegami, I., Kamiya, A. and Hase, E. (1984). Dark formation of Chlorophyll in Cultured Tobacco Cells. Plant and Cell Physiology. 25: 343-348.

Jensen, W. (1962). Botanical Histochemistry. W.H. Freeman and Company. New York. pp 89-90.

Jansson, S; Virgin, I; Gustafsson, P; Andersson, B; Öquist, G. (1992). Light-Induced Changes of Photosystem II Activity in Dark-Grown Scots Pine Seedlings. Physiologia Plantarum. 84: 6-12.

Kamiya, A.; Ikegami, I. and Hase, E. (1981). Effects of Light on Chlorophyll formation in Cultured Tobacco Cells I. Chlorophyll Accumulation and Phototransformation of Protochlorophyll(ide) in Callus Cells Under Blue and Red Light. Plant and Cell Physiology. 22:1385-1396.

Kasemir, H. and Mohr, H. (1981). The Involvement of Phytochrome in Controlling Chlorophyll and 5-Aminolevulinate Formation in a Gymnosperm Seedling (Pinus sylvestris). Planta. 152: 369-373.

Kirk, J. and Tilney-Bassett, R. (1978). The Plastids. Elsevier, North Holland Biomedical Press. New York.

Kupke, D. and Huntington, T. (1963). Chlorophyll a Appearance in the Dark in Higher Plants: Analytical Notes. Science. 140: 49. 
Lichtenthaler, H. (1987). Chlorophylls and Carotenoids: Pigments of Photosynthetic Membranes. In: Methods of Enzymology. (Vol. 148 Plant Cell Membranes. Packer, L. and Douce, R. (Eds.). Academic Press Inc. San Diego. pp 350382.

Marshall, J. and Ehleringer, J. (1990). Are Xylem-Tapping Mistletoes Partially Heterotrophyic?. Oecologia. 84: 244-248.

Martin, G., Josser, S. Bornman, J. and Vogelmann, T. (1989). Epidermal Focusing and the Light Measurement Within Leaves of Medicago sativa. Physiologia Plantarum. 76: 485-492.

Meinecke, E. (1912). Parasitism of Phoradendron juniperinum libocedri Engelm. Proceedings of the Society of American Foresters. 7: 35-43.

Michel-Wolwertz, M. and Bronchart, R. (1974). Formation of Prolammellar Bodies Without Correlative Accumulation of Protochlorophyllide in Pine Cotyledons. Plant Science Letters. 2: 45-54.

Mohanty, G., Bhuyan, A. and Kumar, K. (1991). Photoregulation of Chlorophyll Loss in Excised Echinochloa colona linc. Leaves. Indian Journal of Experimental Biology. 29: 668-671.

Mohr, H. (1982). Phytochrome and Chloroplast Development. In: Chloroplast Biogenesis. Barker, J. and Baker, N. (Eds.). Elsevier, Amsterdam.

Mukai, Y., Yamamoto, N. and Koshiba, T. (1991). Light-Independent and TissueSpecific Accumulation of Light-Harvesting Chlorophyll a/b Binding Protein and Ribulose Bisphosphate Carboxylase in Dark-Grown Pine Seedlings. Plant and Cell Physiology. 32(8): 1303-1306.

Okada, K., Inoue, I., Satoh, K. and Katoh, S. (1992. Effects of Light on Degradation of Chlorophyll and Proteins During Senescence of Detached Rice Leaves. Plant Cell Physiology. 33: 1183-1191.

Oliveira, L. (1982). The Development of Chloroplasts in Root Meristematic Tissue of Secale cereale L. Seedlings. New Phytologist. 91:263-275.

Palanisamy, K. (1989). Chloroembryo: Its Occurrence, Plastid Pigment formation, Photosynthesis and Biochemical Components. Photosynthetica. 23:234-244.

Porra, R., Klein, O. and Wright, P. (1983). The Proof by 13C-NMR Spectroscopy of the Predominance of the C5 Pathway Over the Shemin Pathway in Chlorophyll Biosynthesis in Higher Plants and of the Formation of the Methyl Ester Group of Chlorophyll From Glycine. European Journal of Biochemistry. 130: 509516.

Rey, L., Sadik, A., Fer, A. and Renaudin, S. (1992). Étude de Quelques Aspects du Métabolisme Carboné et Azoté Chez L'arceuthobium Oxycedri, Gui Nain du Genévrier. Canadian Journal of Botany. 70: 1709-1716. 
Reynolds, E. (1963). The Use of Lead Citrate at High PH as an Electron Opaque Stain in Electron Microscopy. Journal of Cell Biology. 17: 208-212.

Roland, J. and Vian, B. (1991). Electron Microscopy of Plant Cells. Hall, J., and Hawes, C. (Eds.). Academic Press, San Diego. pp 32- 33.

Rudoi, A. and Chkanikova, R. (1988). Dark formation of Chlorophyll in Angiosperms. Fiziologiya Rastenii. 35: 1092-1098.

Sallè, G. (1979). The Endophytic System of Viscum album. Its Anatomy Ultrastructure and Relations With the Host Tissues. In: Proceedings of the Second International Symposium on Parasitic Weeds. Musselman, L., Worsham, L, and Eplee, R. (Eds.). North Carolina State University, Raleigh, NC. 14: 115-127.

Schiff, J. (1972). A Green Safelight for the Study of Chloroplast Development and Other Photomorphogenetic Phenomena. Methods of Enzymology. (Vol. 24. Photosynthesis and Nitrogen Fixation. Part B. Pietro, A. (Ed.). pp 321-322.

Shah, N., Smirnoff, N. and Stewart, G. (1987). Photosynthesis and Stomatal Characteristics of Striga hermonthica in Relation to its Parasitic Habit. Physiologia Plantarum. 69:699-703.

Sherma, J.(1972). Sec. IV. Thin-Layer Chromatography. In: Handbook of Chromatography. Zweig, G. and Sherma, J. (Eds.). C.R.C. Press, Cleveland. pp 89-101.

Stewart, G., and Press, M. (1990). The Physiology and Biochemistry of Parasitic Angiosperms. Annual Review of Plant Physiology and Plant Molecular Biology. 41: 127-151.

Thoday, D. (1956). Modes of Union and Interaction Between Parasite and Host in the Loranthaceae. I. Viscoideae, Not Including Phoradendreae. Proceeding of the Royal Society, B. 145: 531-548.

Tuquet, C. and Sallé, G. (1991). Biochemical Features of Chloroplasts Isolated From Hemiparasitic Angiosperms. In: Fifth International Symposium on Parasitic Weeds. Ransom, J., Musselman, L. Worshom, A. and Parker, C. Nairobi, Kenya. pp 262-269.

Virgin, H., Kahn, A. and Von Wettstein, D. (1963). The Physiology of Chlorophyll Formation in Relation to Structural Changes in Chloroplasts. Photochemistry Photobiology. 2: 83-89.

Virgin, H. and Egnéus, H. (1983). Control of Plastid Development in Higher Plants. In: Photomorphogenesis. Encyclopedia of Plant Physiology, New Series. Shropshire, W. and Mohr, H. (Eds.). Springer, Berlin, Heidelberg, New York,. Vol. 16 A. pp 289-311.

Virgin, H. and Sundqvist, C. (1992). Pigment Formation on Potato Tubers (Solanum tuberosum) Exposed to Light Followed by Darkness. Physiologia Plantarum. 86: 587-592. 
Vogelmann, T. (1989). Yearly Review: Penetration of Light Into Plants. Photochemistry and Photobiology. 50: 895-902.

Yakovlev, M. and Zhukova, G. (1980). Chlorophyll in Embryos of Angiosperm Seeds, a Review. Botaniska Notiser. 133: 323-336. 
APPENDIX A

CHLOROPHYLL BIOSYNTHESIS PATHWAY 
Chlorophyll is an intensely green pigment that acts as a photoreceptor to light energy in the light reaction of photosynthesis. In angiosperms chlorophyll synthesis is converted via the C5 pathway in a series of steps, from 5-aminolaevulinic acid (ALA) to protochlorophyllide which, in the presence of light, is immediately photoreduced by the enzyme protochlorophyllide oxidoreductase to chlorophyllide. The chlorophyllide thus produced is then esterified into chlorophyll a (Castelfranco and Beale 1983) (figure 11).

Chlorophyll production in angiosperms is dependent on two light reactions. They are the photoreduction of protochlorophyllide to chlorophyllide (Castelfranco and Beale 1983) and the photoconversion of phytochrome from phytochrome ${ }_{\mathrm{r}}$ to the physiological active form phytochromefr (Mohr 1982). The active form of phytochrome has several roles in the synthesis of chlorophyll: it is believed responsible for increasing the rate of ALA synthesis, increasing the activity of ALA dehydrase, increasing the rate of esterification of chlorophyllide to chlorophyll a, and increasing the synthesis of chlorophyll $b$. The actual photoreduction of protochlorophyllide is also believed to be controlled by phytochrome (Virgin 1972). A third of the chlorophyll a and all of the chlorophyll $b$ are incorporated into chlorophyll $a / b$ protein complexes. 

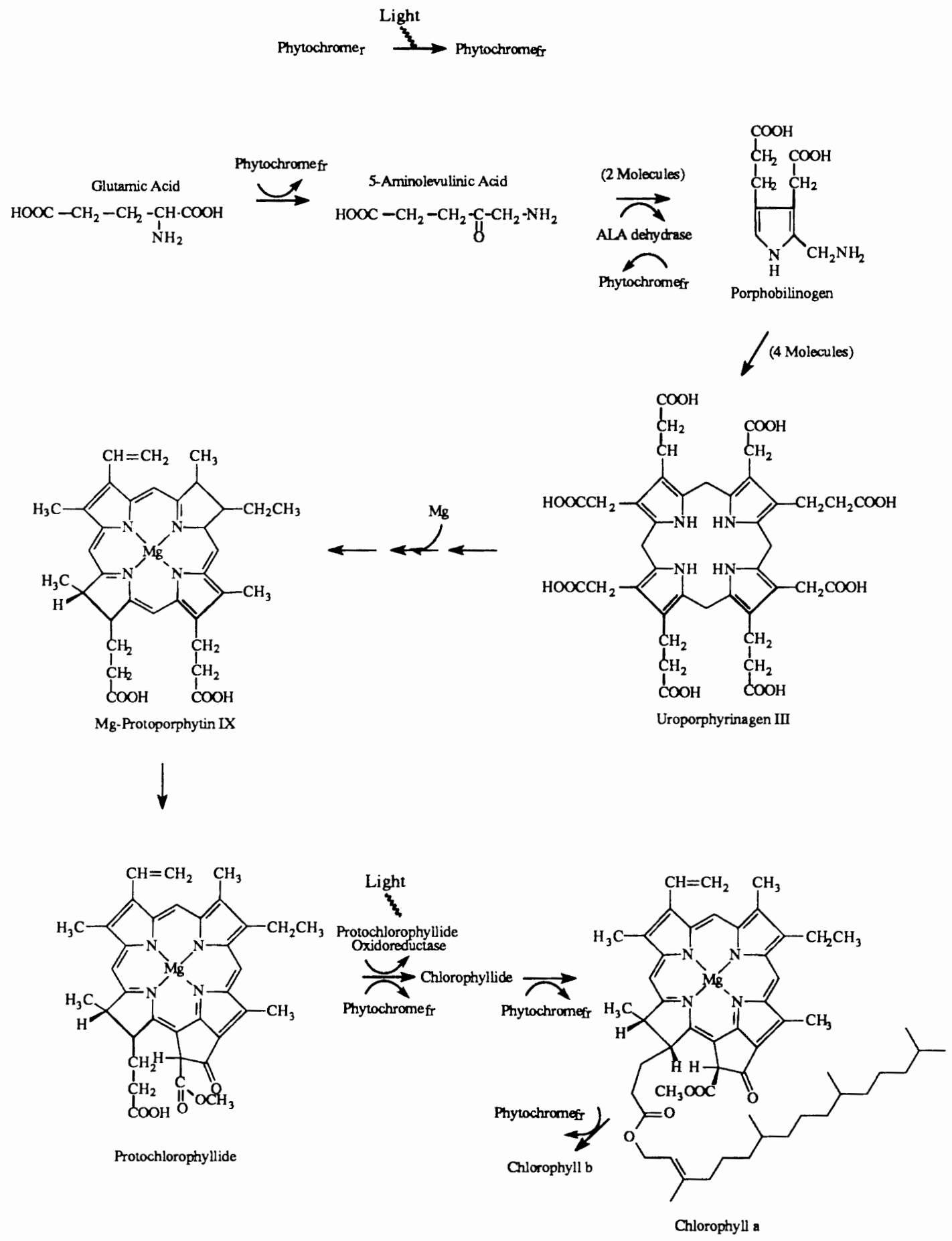

Figure 10. Chlorophyll biosynthesis. 
APPENDIX B

DARK BOX EXPERIMENTS 
To determine if chlorophyll is formed in the dark, plants needed to be grown in the dark. As Phoradendron juniperinum is hard to culture away from its host, boxes were constructed to enclose established infections on the stems of Western Juniper.

A dark box (figure 13) was constructed using four pieces of 1 " $x 4$ " $x 7$ " fir. To allow the two sides of the box to be fitted firmly, a rabbet joint was cut on the long side of the top and bottom pieces. Two 3/8" dados were cut $1 / 4$ " deep, $3 / 4$ " from the ends on the inside of each of the four sides of the box. Precisely down the middle of the dados, a $1 / 8$ " groove was routed to a total depth of $3 / 8$ ". This groove allows for the eventual placement of a piece of slotted $1 / 8$ " thick hard wood. Two other pieces of slotted $1 / 8$ " thick hard wood were eventually fitted (at the time of placement on trees) on either side, one each in the two resulting 1/8" gaps. Each of these three-piece sets was slotted and was used as an entrance or an exit for the infected portion of the host branch. Slots in the hard wood were cut to resemble the silhouette of a thick stemmed lollipop. The lollipop portion was cut 1 " round and in the center of the piece.

Oriented slotted side up, one of the entrance pieces and one of the exit pieces were glued into their appropriate slots on the bottom of the box. To this, both sides of the box were glued, nailed, and caulked to form an open box, making sure the entrance and exit pieces were correctly placed in the appropriate groves. The other two pieces were removable and would be fitted to enclose the host stem. The inner surface of the box was painted black. The outer surface was painted white. Air holes, 7/8" in diameter, were drilled through both sides of the box. Galvanized pipe (7/8" outer diameter (o.d.), $1 / 2$ " inner diameter (i.d.), $11 / 2$ " long, including threads) was put through each of the air holes and secured on the inside with electrical pipe nuts. To prevent light leakage, thick rubber washers were threaded onto the outside of the galvanized pipe. They were held in place by plastic elbows treaded onto the galvanized pipe. Attached to each of these elbows was a section of (approximately one meter long 3/4" i.d.) black irrigation tubing, painted white. These two hoses had a slight bow which was directed inwards as they hung below the box. At the end of each tube was attached another plastic elbow, pointing down.

Foam pluming pipe insulation (3/4" i.d. $11 / 2$ " o.d.) was cut into $5 \mathrm{~cm}$ hollow tubes. Using a soldering iron, a 3/8" wide groove was made around the circumference. These spool shape tubes were split longitudinally so they could be wrapped around the host branch, as detailed below. 


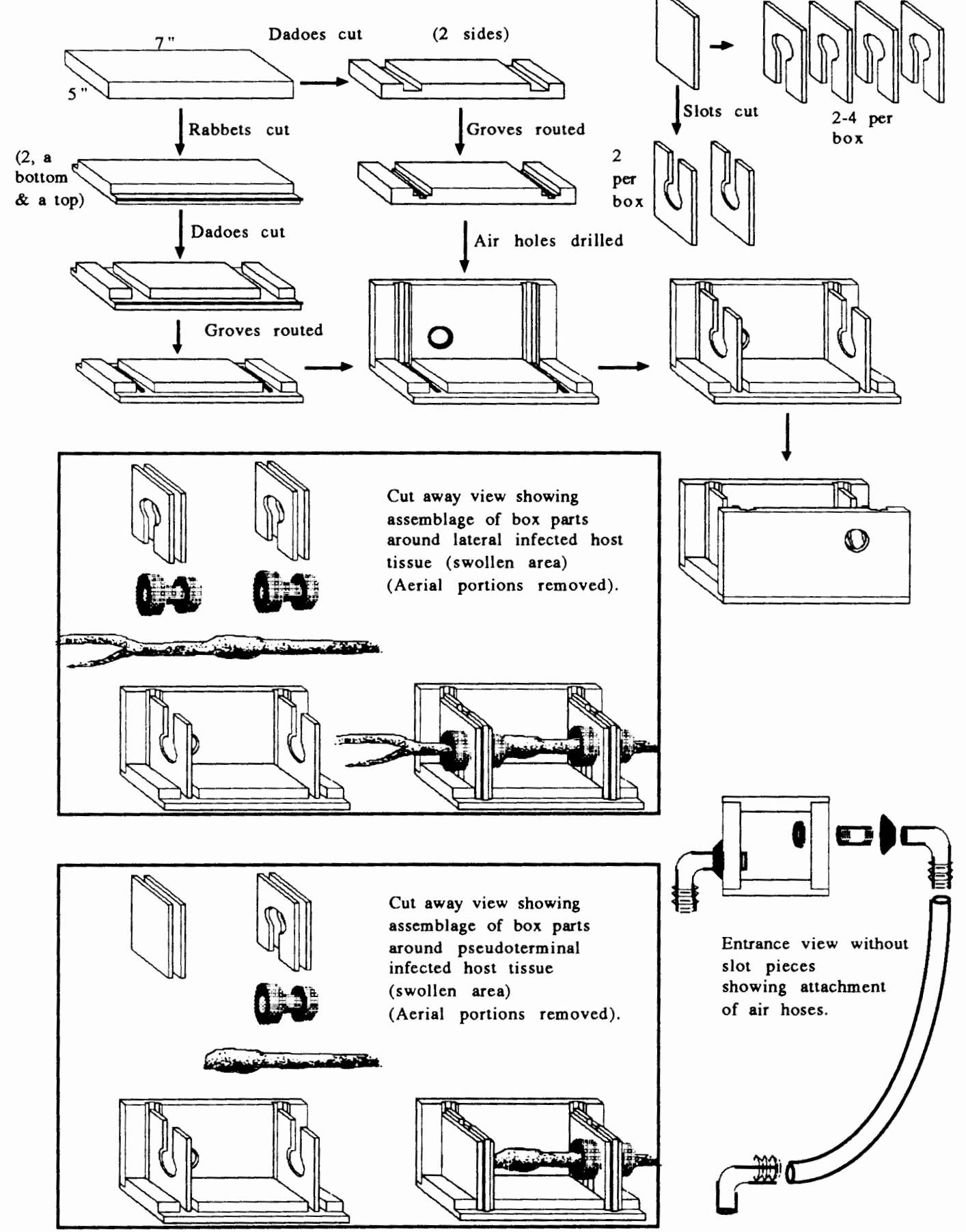

Figure 11. Dark box construction. 
Working under a red safe light, a small strip of $\mathrm{f}_{2}$ photosensitive paper, covered with a red plastic filter, was placed on the bottom of the box, active side up, and covered with black paper. This paper was taped all around to prevent light from prematurely exposing the paper. The paper was attached to a string that was extended through one of the side air hole and down through the end of one of the plastic air pipes. The purpose of the photoactive paper was to test if any light leaked into the box during the duration of the experiment.

Five dark boxes were so constructed.

At each area where the infected host branch would enter and/or exit a box was placed on one of the notched pieces of foam pipe insulation. A dark box was then put around the infected portion of the host branch so that the box's slotted entrance and/or exit fit around the foam insulation notch. The two removable slotted pieces for each of the entrances and exit sets were then fitted, slot side down, as appropriate around the foam insulation notch. The top piece of the box was then heavily caulked and fitted into place. The box was then wrapped around tightly with twine to hold the box together and allow time for the caulk to set. Areas where light might leak in were caulked at this time: entrances, exits, and around box edges. The box was then wrapped well with aluminum foil.

Both lateral and pseudoterminal infections as (defined by Calvin et al. 1991) were examined. If the mistletoe was a lateral infection on the host branch, the branch was fitted into the slots for both the entrance and the exit of the host branch. If the mistletoe was pseudoterminal on the host branch, the exit of the box was sealed with two unslotted exit pieces.

After the aluminum wrapped boxes were in place, the string that was attached to the paper covering the light-sensitive paper was gently pulled through the end of the air tube until it came away from the photosensitive paper, thereby exposing it to any light leakage that might occur throughout the experiment.

Experiments were initiated in April, 1993. Dark boxes number one, two and four were collected on October 13, 1993. Dark boxes number three and five were collected on March 4, 1994. The boxes were collected after sunset using a minimum of flash light illumination. Host branches holding dark boxes were removed from the tree approximately $10 \mathrm{~cm}$ away from both the points of entrance and/or exit of a box. The air hoses were removed with the flashlight off to prevent exposure of the photoactive paper, and rubber stoppers were put into the air holes. The boxes were than put in a 
cooler, on ice, and kept cold and in the dark until the time of pigment extraction and tissue fixation for electron microscopy (within 24 hours).

The removal of the dark boxes from around the infected host branch was done in complete darkness just prior to examination. The photoactive paper was removed from the bottom of the box, labeled and stored in a light proof container. After all plant tissue work was completed, the light exposure of the paper was tested by processing. Any degree of darkening of developed paper indicated light leakage. After 11 months on trees, only one box showed that light exposure had occurred.

Three types of controls were established at the time dark boxes were set-up. Normal mistletoes were left undisturbed to compare changes in pigments and chlorophyll ultrastructure with those of experiments. Some mistletoe had their aerial portions removed, similar to those put into dark boxes. This provided a way for determining if regrowth of aerial shoots occurred and for determining if removal of the aerial shoots had any effect on the chlorophyll content of the endophytic system. The last control involved host stems, which were wrapped with aluminum foil adjacent to an infection. This allowed an indirect determination for the presence of any light conductive tissue that might be providing illumination of the mistletoes endophytic system and, therefore, stimulate chlorophyll synthesis. 